\title{
Megaspore and microfossil assemblages reveal diverse herbaceous lycophytes in the Australian Early Jurassic flora
}

\author{
STEPHEN MCLOUGHLIN ${ }^{1}$, IDA-MARIA JANSSON ${ }^{2,3} \&$ VIVI VAJDA ${ }^{2}$ \\ ${ }^{1}$ Department of Palaeobiology, Swedish Museum of Natural History, Stockholm, Sweden, ${ }^{2}$ Department of Geology, Lund \\ University, Lund, Sweden, ${ }^{3}$ Department of Earth Sciences, University of Toronto, Toronto, Canada
}

\begin{abstract}
Here, we describe and illustrate by transmitted light and scanning electron microscopy the first Australian Jurassic megaspore assemblages. The megaspores and other mesofossils were isolated from terrestrial deposits of the Marburg Subgroup (late Pliensbachian) at Inverleigh Quarry, Clarence-Moreton Basin, eastern Australia. Nine megaspore taxa are identified including one new species: Paxillitriletes rainei. Miospore assemblages recovered from the same samples at Inverleigh reveal a slightly higher diversity of lycophyte microspores. The collective megaspore suite from Inverleigh shares several genera with mid-Mesozoic assemblages from widely distributed parts of the world, but most of the Inverleigh species have subtle morphological differences from congeneric forms elsewhere. The megaspores accumulated in fluvial floodplain facies and are associated with mostly dissociated isoetalean leaf debris. Other mesofossils in the sampled interval include annelid egg cases, dispersed seeds and charcoal. Invertebrate burrows and possible vertebrate tracks also occur in this succession. Lycophyte macrofossils are otherwise known from only two other Australian Jurassic deposits. The richness of the megaspore and microspore suites attest to a significant diversity of lycophytes in the Australian Jurassic floras not hitherto appreciated from described macrofloras.
\end{abstract}

Keywords: lycophyte megaspores, Isoetales, mesofossils, microspores, Pliensbachian, Clarence-Moreton Basin, Gondwana

The Hettangian-basal Toarcian interval is bracketed by two globally recognised mass extinction events. In the Gondwanan terrestrial realm, the RhaetianHettangian transition is marked by the collapse of the Dicroidium/Falcisporites flora that had dominated most of the Triassic (Anderson et al., 1999). In its place arose a flora rich in Bennettitales, Caytoniales and cheirolepidiacean conifers (Gould, 1975; Hill et al., 1999). A further transition in the Toarcian saw a decline in cheirolepids and increases in araucariacean and podocarpacean conifers and pentoxylalean gymnosperms in Australia (Turner et al., 2009). The Australian Hettangian-Toarcian floras remain poorly understood, being represented by only a few macrofloral assemblages from central eastern Australia that have yet to be fully described (Jones \& de Jersey, 1947; Gould, 1968, 1974, 1975;
Pattemore, 2000; Pattemore \& Rigby, 2005; Jansson et al., 2008b). Palynofloras provide a broader picture of Australia's Early Jurassic floristic succession (Evans, 1966; de Jersey, 1975; Filatoff, 1975; Burger, 1976, 1994; Helby et al., 1987; Turner et al., 2009), but the biological affinities of some palynomorphs remain poorly resolved (Balme, 1995) and spore-pollen assemblages may be subject to significant taphonomic sorting (Holmes, 1994). Mesofossils $(0.2-5.0 \mathrm{~mm}$ remains including megaspores, sporangia, seeds and charcoalfied plant fragments) represent an additional avenue for evaluating fossil plant diversity. However, mesofossil suites have been largely neglected in past palaeobotanical studies of the Australian Jurassic.

Thus far, the only records of megaspores in the Australian Jurassic are rare specimens encountered

Correspondence: Stephen McLoughlin, Department of Palaeobiology, Swedish Museum of Natural History, Box 50007, S-104 05 Stockholm, Sweden. E-mail: steve.mcloughlin@nrm.se

(Received 6 fuly 2013; accepted 13 August 2013) 
in palynological assemblages from the Perth Basin, Western Australia (Filatoff, 1975), and none has been formally described. Despite this apparent dearth of material, lycophyte megaspores are abundant in many mid-Mesozoic mesofossil assemblages from other parts of the world (Batten \& Kovach, 1990) and in both older and younger Mesozoic deposits of Australia (Scott \& Playford, 1985; McLoughlin et al., 2002; Tosolini et al., 2002), and their temporal distribution offers considerable potential for use as biostratigraphic markers (Kovach \& Batten, 1989).

Jansson et al. (2008a, 2008b) described, thus far, the best known Australian Early Jurassic macrofloral assemblage together with clitellate annelid remains from a thin floodbasin succession within the Marburg Subgroup at Inverleigh in the ClarenceMoreton Basin. Subsequently, Steinthorsdottir and Vajda (2013) reconstructed the atmospheric carbon dioxide concentration $\left[p \mathrm{CO}_{2}\right]$ for the late Pliensbachian based on stomata density analysis of conifer leaves from the Inverleigh assemblage, highlighting the potential of Australian fossil conifers in palaeo- $p \mathrm{CO}_{2}$ reconstructions.

During the course of those investigations, megaspores were detected in bulk-(hydrofluoric acid)macerated siltstone samples from the Inverleigh deposit. Here we describe those megaspore assemblages as a case study to evaluate the abundance and diversity of lycophyte mesofossils and microfossils in the Early Jurassic of Australia. We reassess the age and depositional environment of the host strata based on refined palynostratigraphy and sedimentological analysis. The macrofossil record of lycophytes in the Jurassic of Australia is summarised to provide context for understanding the likely parent plants of the dispersed megaspores.

\section{Lycophyte macrofossils in the Australian Jurassic}

Although lycophytes (especially herb- to shrub-sized Isoetales and Pleuromeiales) apparently underwent a pulse of diversification in Gondwana following the end-Permian mass extinction (Retallack, 1977, 1997; White, 1981b; Cantrill \& Webb, 1998; Vajda \& McLoughlin, 2007), no such radiation has been recorded in the wake of the end-Triassic event (de Jersey \& Raine, 1990; Akikuni et al., 2010; de Jersey \& McKellar, 2013). By the Jurassic, heterosporous lycophytes were mostly represented by herbaceous, and in many cases, semi-aquatic plants (Pigg, 1992).

Thus far, the role of lycophytes in Australian Jurassic floras has been largely overlooked owing to the scarcity of macrofossils attributed to this group. Cavate trilete lycophyte microspores have been widely reported in Australian palynofloras (de Jersey \& Paten, 1964; Filatoff, 1975; Backhouse, 1988), but their abundance is never great and their diversity has not been thoroughly evaluated. Nevertheless, several lycophyte microspore species have been used to define interval biozones in the Jurassic and Cretaceous of Australia and New Zealand (Helby et al., 1987; Raine, 2008), so the group has considerable biostratigraphic importance in the mid- to late Mesozoic of south-eastern Gondwana.

Only three macrofossils confidently attributable to lycophytes have been documented from the Australian Jurassic. This scarcity is surprising given that Jurassic macrofloras are common and widespread in Australia (Gould, 1975, 1980; McLoughlin \& Hill, 1996; Hill et al., 1999; McLoughlin \& Pott, 2009; Turner et al., 2009), and some individual assemblages are represented by large collections in museums. The three confident records are: ramifying leafy axes attributed to Lycopodites gracilis (Morris) Seward et Sahni, 1920 reported by Rigby (1978) from the Middle Jurassic Walloon Coal Measures; a single leafless corm from the Upper Jurassic Pilliga Sandstone (White, 1986); and dispersed isoetalean microphylls from the Lower Jurassic Marburg Subgroup (the same site from which the presently described megaspores were recovered; Jansson et al., 2008b). Other examples reportedly from the Jurassic of Australia are wrongly dated or misidentified. Lycopodites victoriae Seward, 1904 , originally reported to be from the Jurassic of the Gippsland Basin, Victoria, has subsequently been assigned an Early Cretaceous age (Douglas, 1969). Similarly, Isoetites elegans Walkom, 1944, described from the Leederville Formation of the Perth Basin, Western Australia, and originally regarded as Jurassic (Ash \& Pigg, 1991), was subsequently also dated as Early Cretaceous (McLoughlin, 1996). Gould (1975) favoured a Late Jurassic age for a macroflora from Cape York Peninsula described by Walkom (1928) that contained two Lycopodites species. However, palynological data from the host unit (the Gilbert River Formation) favours an Early Cretaceous age (Burger, 1973, 1980, 1982). The record of Selaginella sp. from the Upper Jurassic Talbragar Fossil Fish Bed (White, 1981a, figure 53; Beattie \& Avery, 2012, figure 9F) is dismissed, since this fossil lacks the leaf arrangement typical of that genus (Webster, 1992) and has cup-shaped reproductive structures (S. McLoughlin, pers. obs., August 2013). It is conceivable that the linear leaves in dense mats illustrated by McLoughlin and Drinnan (1995, figure 4E) from the Middle Jurassic Walloon Coal Measures of the Clarence-Moreton Basin represent dispersed isoetalean microphylls but their 
disaggregated state and poor preservation makes confident identification impossible.

All confirmed Jurassic records derive from eastern Australia and represent herbaceous taxa. Their small stature is consistent with the general reduction series hypothesised for heterosporous lycophytes through the Permian and Mesozoic (Pigg, 1992), although some Gondwanan isoetaleans, selaginellaleans and possible lycopodialeans had already attained specialised herbaceous habits by the end of the Palaeozoic (Phillips \& Leisman, 1966; Townrow, 1968; Holdgate et al., 2005; Schwendemann et al., 2010; Ryberg et al., 2012).

The specimen of Lycopodites gracilis recorded from the Walloon Coal Measures by Rigby (1978) was not registered in an institutional collection and a line drawing based on the original published photograph is provided here (Figure 1A). The specimens have equal to unequally dichotomising prostrate axes bearing a single row of microphylls along the lateral margins. This specimen is similar in gross architecture to a range of other Mesozoic bifurcating prostrate leafy axes attributed to Lycopodites (Lundblad, 1950) and likely represents a member of the Selaginellales.

Isoetalean remains recorded by Jansson et al. $2008 b$, figure $5 \mathrm{H}$, I) consist of isolated linear microphylls and, in a few cases, apparent laterally compressed clusters of attached microphylls (Figure 1B). The corm from the Pilliga Sandstone (White, 1986) has never been formally described and is re-illustrated here to show its gross morphology in lateral and basal view. It consists of a $51 \mathrm{~mm}$ tall, $33 \mathrm{~mm}$ diameter inverted urn-shaped corm (Figure 1D) that is basally divided into four weakly defined lobes (Figure 1C). This lobate corm with tightly spaced, spirally arranged, slit-like microphyll scars is similar to forms attributed to Nathorstianella babbagensis (Woodward) Glaessner et Rao, 1955 from the Early Cretaceous of South and Western Australia (Karrfalt, 1986; McLoughlin, 1996) and likely represents a herbaceous isoetalean.

Dispersed megaspores in the Australian Jurassic may, thus, derive from either Selaginellales or Isoetales, though none of the megaspores in the

Figure 1. A. Lycopodites gracilis, redrawn from Rigby (1978), from the Middle Jurassic Walloon Coal Measures, Clarence-Moreton Basin (unregistered specimen, current location unknown). B. Cluster of linear isoetalean microphylls from the Lower Jurassic Marburg Subgroup at Inverleigh Quarry, Clarence-Moreton Basin, QMF52592. C, D. Isoetalean corm from the Upper Jurassic Pilliga Sandstone, Surat Basin, originally illustrated by White (1986), MMF25282: C. Basal view; D. Lateral view. Scale bars $-10 \mathrm{~mm}$. present study displays the iridescence generated by the stacking of sporopollenin structural units in the spore wall that is a feature of some selaginellaleans (Hemsley et al., 1994).
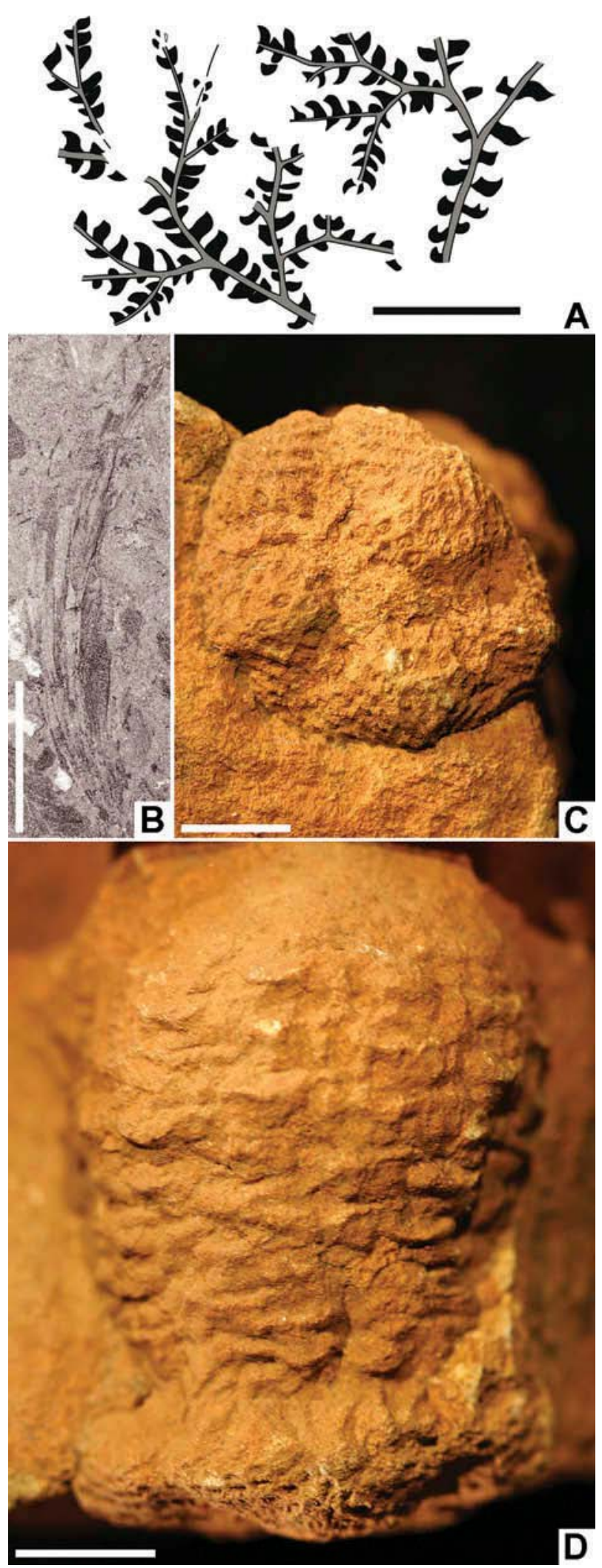


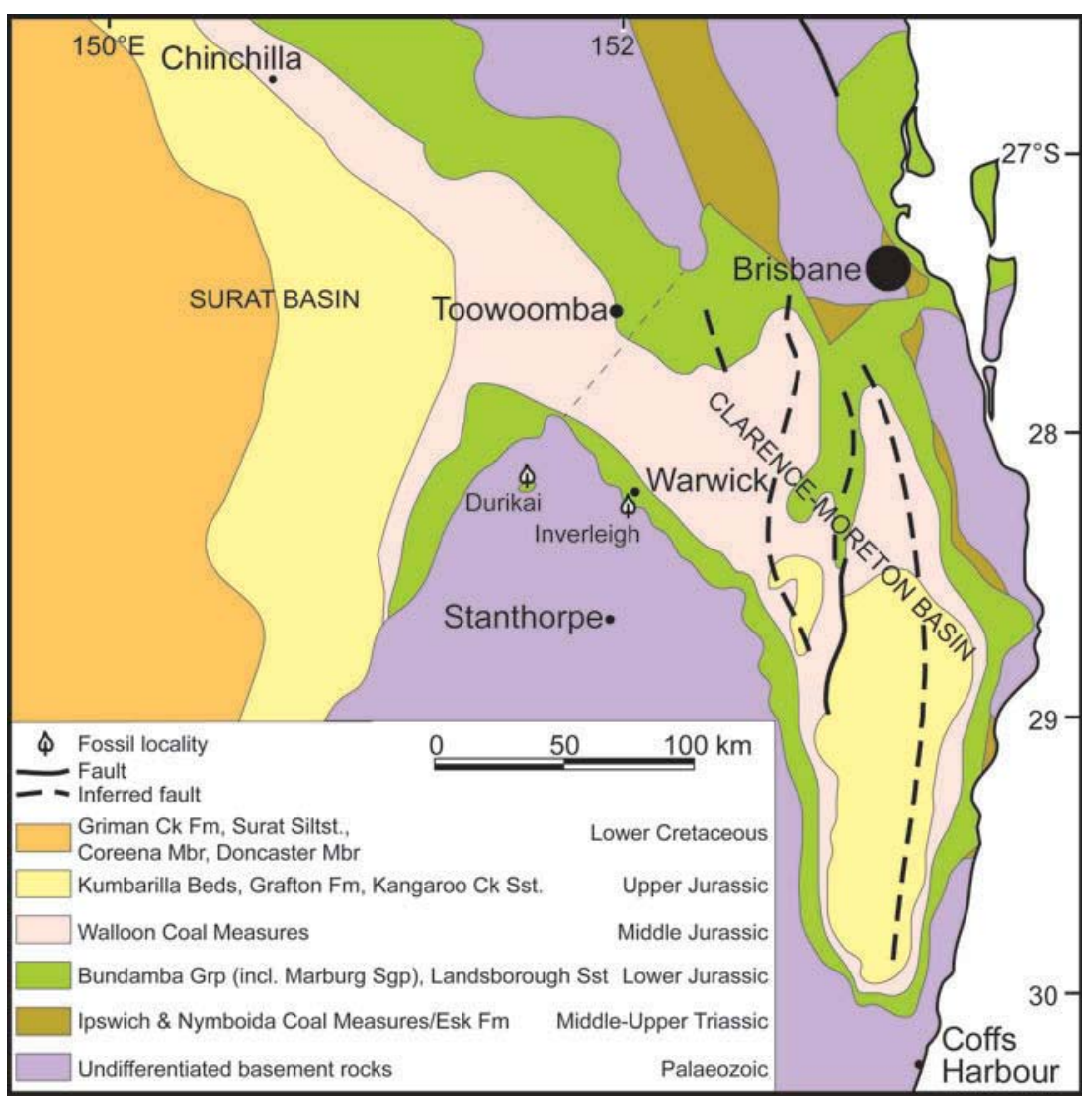

Figure 2. Simplified geological map of the Clarence-Moreton Basin showing the location of the studied section at Inverleigh and the coeval Durikai deposit studied by Gould (1971).

\section{Geological setting, material and methods}

\section{Geological setting}

The studied samples were obtained from the Marburg Subgroup exposed within a quarry near Inverleigh $\left(28^{\circ} 17^{\prime} 02.87^{\prime \prime} \mathrm{S}, 151^{\circ} 58^{\prime} 55.64^{\prime \prime} \mathrm{E}\right)$ that is currently used as a source of brick-making materials, in the north-western part of the Clarence-Moreton Basin, southeast Queensland, Australia (Figure 2). The Marburg Subgroup represents a succession of mature, mainly quartzose, sandstones and shales deposited by mixed sinuosity, predominantly northward-flowing rivers (Cranfield et al., 1975; O'Brien \& Wells, 1994). This subgroup is undifferentiated in the Inverleigh area but palynological evidence suggests correlation of the sampled interval with the lower part of the unit represented by the Gatton Sandstone in the eastern part of the basin (Wells \& O'Brien, 1994; Goscombe \& Coxhead, 1995) and supports a late Pliensbachian age (c. 185-183 Ma: Jansson et al., $2008 b$, and see palynostratigraphy section). The studied deposits were laid down at latitudes of $c .55^{\circ} \mathrm{S}$ in the Early Jurassic (Veevers, 2000).

The quarry exposes strata referable to two distinct sedimentary facies associations characteristic of a lowsinuosity fluvial system (see Jansson et al., 2008a, figure 3). The lower succession, dominated by finegrained sediments, was deposited in a floodbasin setting and incorporates three main lithofacies (A-C: Figures 3, 4C-H). The upper part of the succession incorporates repetitive, thick, sandstone packages attributed to lithofacies D (Figures 3, 4A), which characterises sandy braided channel deposits.

Lithofacies A consists of shaley bituminous coal to coaly shale, locally grading to strongly carbonaceous siltstone. Fine clastic partings within the coals are rich in clays and muscovite. Beds are thinly flatlaminated and locally host thin ferruginous layers, lenses or small concretions. Beds are generally thin $(<15 \mathrm{~cm})$ and laterally impersistent, lensing out over $<50 \mathrm{~m}$ into lithofacies B. Lithofacies A typically shows gradational lower and upper contacts against beds of lithofacies B. The facies is rich in plant fossils (Figure $4 \mathrm{H}$ ), but most remains are fragmentary in the shales or homogenised in the coals.

This facies is typical of accumulations of organic detritus in a floodbasin mire (Fielding, 1984). Underlying beds are generally rich in fossil roots suggesting that much of the organic matter contributing to the peat is autochthonous/parautochthonous. Peat accumulation was interrupted by episodic fine clastic input to the mire.

Lithofacies B consists of variably pale to dark grey siltstone with sporadic thin laminae or lenses of fine to very fine subfeldsarenite (Figure 4E). Packages range up to $1.7 \mathrm{~m}$ thick but these may contain 


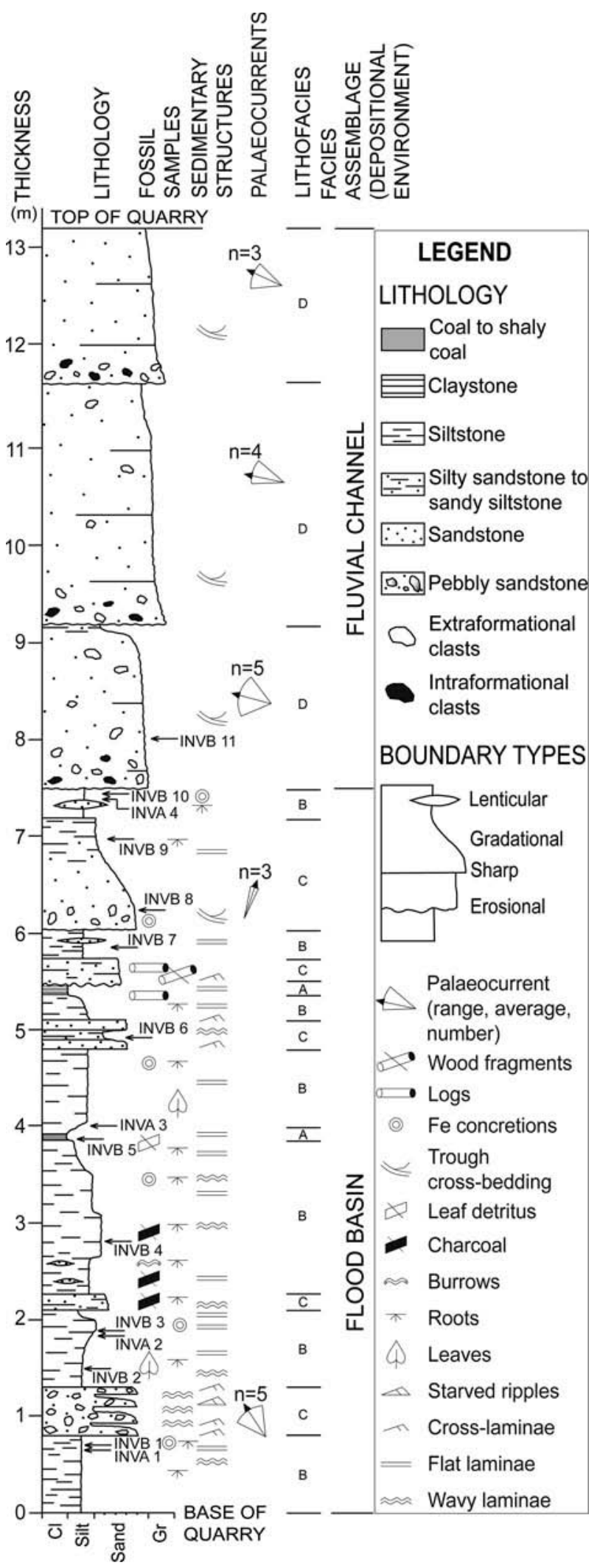

Figure 3. Sedimentary log of the Marburg Subgroup exposed in the Inverleigh Quarry, western Clarence-Moreton Basin, showing the stratigraphic positions of megaspore and miospore samples and the distribution of lithofacies. Megaspores were studied only from INVB samples. Miospore suites were studied from both INVA and INVB samples. several gradationally bounded beds (generally 15$30 \mathrm{~cm}$ thick) that are alternately more sand- or siltrich. Beds are typically flat or wavy laminated, but convoluted bedding is locally developed. Ferruginous laminae and small concretions are present, especially near the contact of this facies with overlying sandy beds of lithofacies D. Beds attributed to facies B are generally persistent for $>100 \mathrm{~m}$. Rootlets (Figure 4F), horizontal to vertical sandfilled burrows (Figure 4C, E), and annelid egg cases (Jansson et al., 2008a) are common within this facies. Charcoalified wood fragments are locally abundant. Foliar remains are generally fragmentary. Well-preserved leaf and short shoot impressions and compressions are preserved in a few beds and these are the source of the macrofossil assemblages described by Jansson et al. (2008b).

This facies represents fine clastic material deposited under quiet-water conditions. Although plant remains are locally abundant and extensive rootlet horizons attest to a richly vegetated floodplain, organic matter accumulation was not sufficient to develop peat. This amalgamation of beds is equivalent to the collective mudrock facies assemblage described by Rust and Jones (1986) and is interpreted to represent floodplain settings distal to the channel, with episodic fine clastic input alternating with subaerial exposure, pedogenesis and colonisation of the sediment surfaces by herbaceous to woody vegetation.

Lithofacies $\mathrm{C}$ represents composite packages (up to $50 \mathrm{~cm}$ thick) consisting of 5 to $20 \mathrm{~cm}$ thick beds of fineto coarse-grained, buff to brown subfeldsarenite alternating with $<3 \mathrm{~cm}$ laminae of carbonaceous to micaceous sandy siltstone. In rare cases, the facies packages may reach $1.2 \mathrm{~m}$ thick and constitute a single upwardfining bed of coarse-grained sandstone to siltstone. The sandstones are typically cross-laminated (Figure 4D) and some contain sparse pebbles of milky quartz and chert. A few beds are massive, chaotically sorted or possess poorly developed trough cross-beds. Siltstones display flat or wavy laminae. Upper contacts of this facies (usually against lithofacies B) are sharp; lower boundaries (against lithofacies A or B) are sharp to erosional. Packages are generally persistent for $>50 \mathrm{~m}$ but some interdigitate with sediments of lithofacies B. North-westerly to northerly, palaeocurrents were recorded from cross-laminae within this facies. Log impressions, compressions and charcoalified wood fragments are scattered throughout but root traces are sparse at the top of only a few packages (Figure 3).

The relatively thin, wedge-like, sandstone packages with sharp basal contacts, irregularly distributed logs and, in some cases, pebbly and chaotic bedding, suggest deposition of lithofacies $\mathrm{C}$ in crevasse splays (equivalent to facies B3 of Fielding, 1993). The sediments are interpreted to have been 


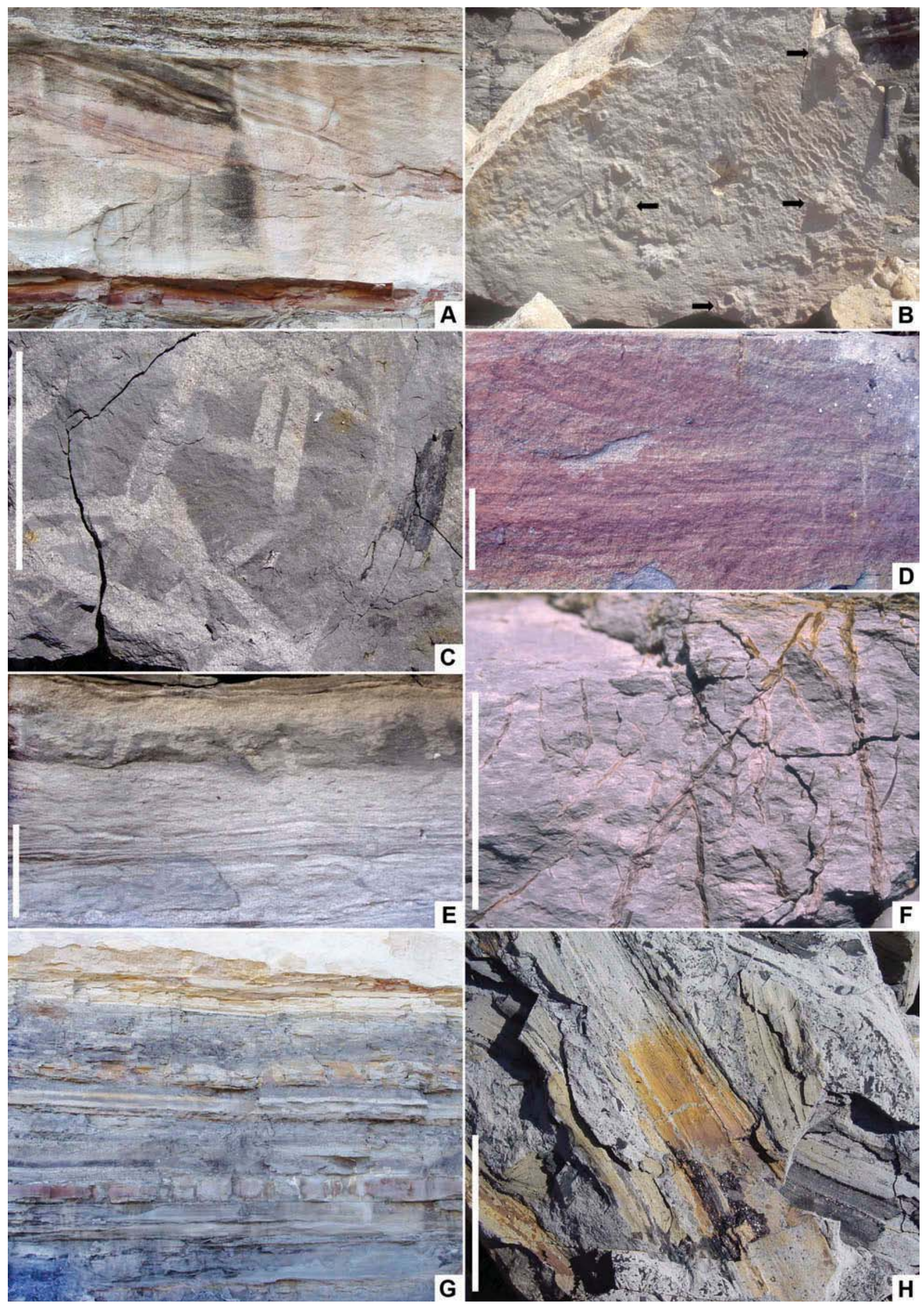


deposited by floods of variable magnitude inundating the floodplain.

Lithofacies D represents thick $(1.5-2.5 \mathrm{~m})$, multistorey packages of white to buff granulestone to coarse-grained quartz arenite, or subfeldsarenite (Figures 3, 4A). Packages are trough cross-stratified, commonly hosting both extraformational (milky vein quartz and chert) and intraformational (fine sandstone and siltstone) clasts up to $10 \mathrm{~cm}$ in diameter. Log impressions up to $30 \mathrm{~cm}$ in diameter, possible vertebrate tracks, and low-energy sedimentary structures, such as current ripples, are evident on thin silty partings between the sandstones (Figure 4B). Much of the original feldspar content of the sandstones has been altered to kaolinite by post-Jurassic weathering. Load casts are present at the base of some beds. Both basal and upper contacts are typically erosional. Palaeocurrent directions from crossbedding are generally orientated to the west or northwest.

These thick, coarse-grained, erosionally bounded packages are interpreted to be high-energy channel deposits. They are equivalent to facies $\mathrm{Sp}$ of Miall's (1977) lithofacies scheme for braided rivers and represent the deposits of large-scale subaqueous sandy dunes. The relatively uniform palaeocurrent orientations suggest deposition by low-sinuosity rivers and are consistent with westerly to north-westerly sediment transport reported for the Marburg Subgroup by O'Brien and Wells (1994).

\section{Material and methods}

Megaspores, other mesofossils and miospore suites were obtained mostly from grey sandstones and siltstones with thinner beds of darker, carbonaceous shales collected initially for the recovery of plant cuticles (Jansson et al., 2008b). Two sample suites were used for palynology. Initially, four samples were investigated for palynostratigraphic resolution in the studies by Jansson et al. (2008a, 2008b). Subsequently, an additional set of 11 samples was collected and processed for palynology, these being split from the same samples studied for mesofossils. The palynological results from the two sample sets were merged for this study, to provide a total batch of
15 samples. Samples collected during the initial surveys by Jansson et al. $(2008 a, 2008 b)$ are labelled INVA1-4; those collected for the present study are labelled INVB1-11.

Mesofossil extraction involved sediment samples of c. $150 \mathrm{~g}$ being bulk-macerated in cold $40 \%$ hydrofluoric acid for five to eight days. Residues were washed with distilled water, sieved using a $63 \mu \mathrm{m}$ mesh, and then sorted in a petri dish using a hair brush under a light microscope. Some material was subsequently mounted on scanning electron microscopy (SEM) stubs and coated with gold prior to examination with a Hitachi S-3400N scanning electron microscope at Lund University, Lund, Sweden, and a Hitachi S-4300 field emission scanning electron microscope at the Swedish Museum of Natural History, Stockholm, Sweden. The palynological samples for this study were processed at Global Geolab Ltd., Alberta, Canada, following standard palynological processing techniques. This involved removal of carbonates with $10 \%$ hydrochloric acid and the removal of silicates with $37 \%$ hydrofluoric acid; the residues were subsequently boiled in $10 \%$ hydrochloric acid and, when necessary, oxidised for $<15$ minutes in concentrated nitric acid.

Spore morphological terminology follows the scheme of Punt et al. (2007). Measurements of specimens are based on their dry dimensions, which are generally about $80 \%$ of their hydrated size. Measurements and dimensional ranges of mesofossils are based on all available specimens of respective taxa. Mesofossils and palynomorphs are stored in the collections of the Swedish Museum of Natural History, Stockholm (prefixed NRM S), and the Department of Geology, Lund University, Lund (prefixed LO). Illustrated macrofossils are stored in the collections of the Queensland Museum, Brisbane, Australia (prefixed QMF), and the Geological Survey of New South Wales, Londonderry, New South Wales, Australia (prefixed MMF).

\section{Results}

Ten of the 11 samples (INVB1-11: Figure 3) yielded identifiable mesofossils including nine megaspore taxa, but only five samples yielded megaspores

\footnotetext{
Figure 4. Sedimentary facies represented in the Marburg Subgroup at Inverleigh Quarry, southeast Queensland. A. Large-scale planar cross-bedding in pebbly sandstone (facies D); package thickness $c .2 .5 \mathrm{~m}$. B. Undersurface of a facies D sandstone cross-bed set showing ripple marks and possible vertebrate track casts (arrowed); hammer - $32 \mathrm{~cm}$ long. C. Facies B bedding plane showing abundant sand-filled burrows. D. Cross- and planar-laminated sandstones of facies C. E. Mixed lithologies of facies B with prominent vertical to oblique sandfilled burrows beneath sandstone bed. F. Root traces in mottled palaeosol developed in facies B siltstone. G. Interstratified packages of facies $\mathrm{A}-\mathrm{C}$ in the lower part of the sampled succession; figured section $c .6 \mathrm{~m}$ thick. $\mathbf{H}$. Abundant woody and leafy debris in facies A shale. Scale bars $-5 \mathrm{~cm}(\mathrm{D}-\mathrm{F}, \mathrm{H}), 5 \mathrm{~mm}(\mathrm{C})$.
} 
in significant abundance (i.e. $>15$ specimens: Table I).

\section{Description of megaspores}

Phylum LYCOPHYTA

Trileites Erdtmann ex Potonié, 1956

Type species. - Trileites spurius (Dijkstra) Potonié, 1956; Early Cretaceous, The Netherlands.

Trileites sp. cf. T. pinguis (Harris) Potonié, 1956 (Figure $5 \mathrm{~A}-\mathrm{K}$ )

Material. — NRM S089648, NRM S089650, NRM S089651, NRM S089655, NRM S089656, NRM S089661.

Description. - Spherical to ellipsoidal megaspore, in most cases strongly flattened through compaction (Figure 5A, B, G, J), typically $450-490 \mu \mathrm{m}$ in equatorial diameter, $530 \mu \mathrm{m}$ in polar diameter (rare diminutive forms reach only $200 \mu \mathrm{m}$ in equatorial diameter); amb circular. Laesurae straight or weakly sinuous at the pole, extending almost to the equator, reaching $50 \mu \mathrm{m}$ high at the poles but flattening and broadening at their equatorial limit where they are locally flanked by minute grana (Figure 5K). Contact areas laevigate and delimited only by weakly defined curvaturae ridges in a few specimens (Figure 5G, J). Distal surface laevigate (Figure $5 \mathrm{E}$ ) or rarely with sparse, irregularly positioned $<2 \mu \mathrm{m}$ diameter grana or ubisch bodies. Spore wall c. 13-20 $\mu \mathrm{m}$ thick (Figure 5F, I), finely porous (Figure $5 \mathrm{H}$ ), with an ill-defined sponge-like internal structure (Figure 5I). Inner surface of spore wall unornamented or scabrate (Figure 5C, F).

Remarks. - Similar laevigate or sparsely granulate megaspores have been assigned to a broad range of species within genera such as Trileites and Banksisporites. Since a partially detached internal mesospore is not discernible in the Inverleigh specimens, we assign them to Trileites rather than Banksisporites. The dearth of distinctive morphological characters makes it difficult to assign these spores to any established species with confidence. However, the specimens are markedly smaller (one-half to two-thirds the diameter) than otherwise similar Early Cretaceous forms from Argentina assigned to Trileites spp. by Baldoni and Batten (1997). They are within the size ranges of Trileites pinguis and Banksisporites sinuosus Dettmann, 1961 from the Late Triassic of
Tasmania, although the Tasmanian forms of T. pinguis appear to have contact areas demarcated by narrow ridges. European examples of $T$. pinguis have flatter or concave contact areas that are not clearly demarcated by such ridges (see e.g. Kempf, 1971; Batten, 1995). Oxidised specimens of Cabochonicus sinuosus Cantrill et Drinnan, 1994 from the Late Triassic of Antarctica are also similar in morphology, although generally markedly smaller than the Inverleigh specimens. A range of Triassic and Cretaceous Laurasian forms assigned to taxa such as aff. Maexisporites politus (Dijkstra) Potonié, 1956, the megaspores of Pleuromeia rossica Neuburg, 1960, Trileites sp. cf. T. persimilis (Harris) Potonié, 1956, Trileites muelleri Kozur, 1973 and T. murrayi (Harris) Marcinkiewicz, 1971 are also similar to these Inverleigh megaspores (Batten, 1988; Koppelhus \& Batten, 1989; Marcinkiewicz, 1992; Lugardon et al., 2000; Batten et al., 2010; Lupia, 2011), but subtle differences in the robustness, sinuosity and extent of the laesurae, together with their great temporal and geographic separation suggest that they represent distinct species.

Trileites sp. cf. T. subdeltoides (Dijkstra) Potonié, 1956 (Figures 6A-L, 7D)

Material. — NRM S089553, NRM S089567, NRM S089569, NRM S089586, NRM S089589, NRM S089590, NRM S089591, NRM S089592, NRM S089595, NRM S089600, NRM S089603, NRM S089653, NRM S089669.

Description. - Strongly compressed and folded megaspores (Figure 6A, B, K, L) suggesting a thin wall; distal side hemispherical (Figure $6 \mathrm{H}$ ), proximal hemisphere forming a low pyramid (Figure 6C); amb convexly subtriangular to subcircular. Equatorial diameter 190-860 $\mu \mathrm{m}$, polar diameter c. 160$560 \mu \mathrm{m}$. Laesurae extend to the equator and incorporate relatively straight and smooth margines up to $25 \mu \mathrm{m}$ high and $<5 \mu \mathrm{m}$ wide. Margines flare at their equatorial ends and continue as sharp-edged ridges that encircle the contact areas and essentially form a narrow zona (Figure 6J). Contact areas locally bearing low apiculae, $<5 \mu \mathrm{m}$ high and $<6 \mu \mathrm{m}$ in basal width, especially near the pole (Figure 6F). Ornament sparsely scabrate to laevigate towards the equator (Figure 6G, I). Distal surface apparently laevigate (Figure 6D, E). Rare aggregated (immature?) forms are smaller than typical representatives and have thinner walls (Figure 7D).

Remarks. - These Inverleigh specimens are most similar to Trileites subdeltoides from the Cretaceous 


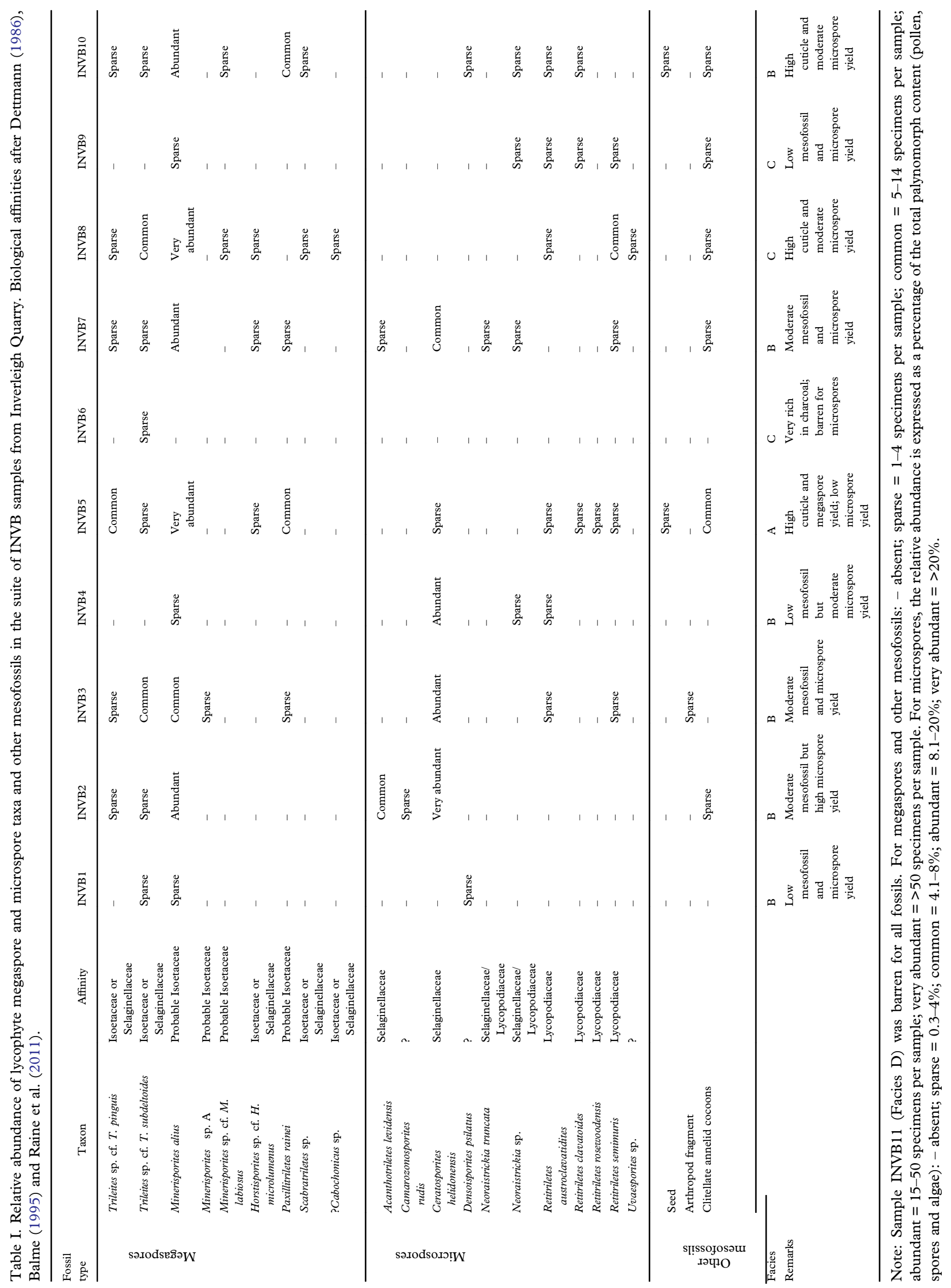



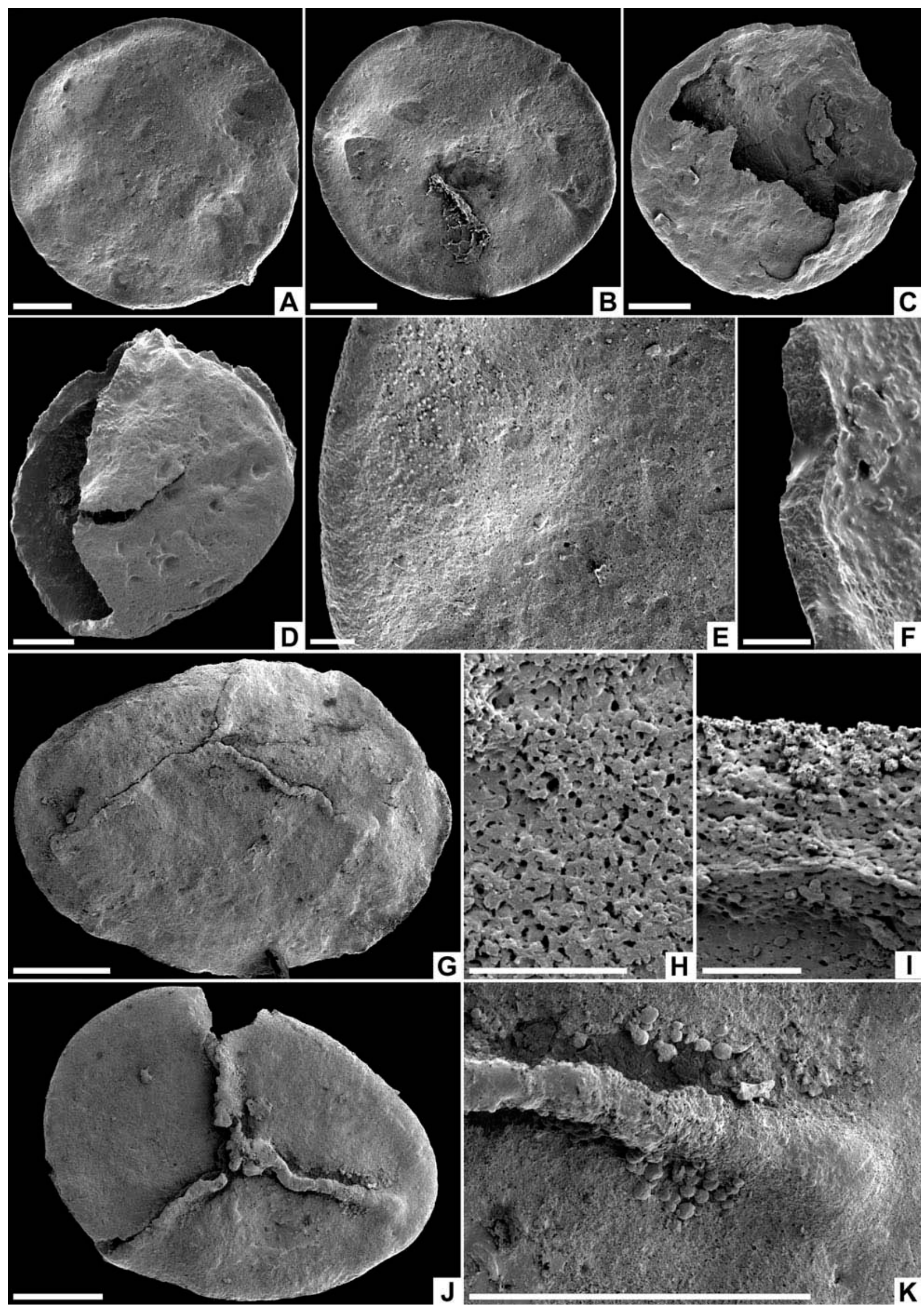
of Europe in their small size, subtriangular outline, laevigate surface and commonly wrinkled or creased appearance (Dijkstra, 1951; Batten, 1995). Only the presence of weak sculptural elements near the proximal pole differentiates the Australian specimens. Maexisporites (Breviornatisporites) sp. cf. M. pusillus Li and Batten, 1987 (in Li et al., 1987) from the Aptian of Germany (Batten, 1995; Wierer, 1998) has similar subdued sculpture near the proximal pole, but has less robust laesurae and a more circular amb. Although laevigate with prominent laesurae and flanges around the contact areas, Banksisporites kachchhensis Banerji, Jana et Maheshwari, 1984 from the Early Cretaceous of India has a more circular amb and distinctly sunken contact areas. Saccarisporites sp. from the Early Cretaceous of India (Sukh Dev, 1961, plate 3, figure 21) was described as lacking a trilete mark, although one appears to be present in the figured specimen. That form is otherwise similar to Trileites sp. cf. T. subdeltoides in its subtriangular amb and thin, laevigate wall.

Minerisporites Potonié, 1956 emend. Batten et Koppelhus, 1993

Type species. - Minerisporites mirabilis (Miner) Potonié, 1956; Paleocene, Montana.

Minerisporites alius Batten, 1969

(Figures 7E-G, 8A-O)

Material. - NRM S089549, NRM S089551, NRM S089554, NRM S089556-S089566, NRM S089568, NRM S089570, NRM S089571, NRM S089573S089578, NRMS089581-S089583, NRM S089585, NRM S089587, NRM S089588, NRM S089593, NRM S089594, NRM S089596-S089599, NRM S089601, NRM S089602, NRM S089604, NRM S089606-S089609, NRMS089642, NRM S089644,
NRM S089646, NRM S089647, NRMS089649, NRM S089654, NRM S089657-S089660, NRM S089662, NRM S089664-S089668.

Description. - Megaspore with convexly subtriangular to subrounded amb (Figures $7 \mathrm{E}-\mathrm{G}, 8 \mathrm{E}, \mathrm{H}, \mathrm{I}$ ); distal half hemispherical (Figure $8 \mathrm{~J}$ ); proximal half forming a low dome or pyramid (Figure 8A, C); equatorial diameter $230-545 \mu \mathrm{m}$ including auriculae. Polar diameter $185 \mu \mathrm{m}$. Laesurae mostly straight, extending to equator and onto short radial auriculae (Figure $7 \mathrm{~F}, \mathrm{G}$ ). Margines up to $40 \mu \mathrm{m}$ high, $5 \mu \mathrm{m}$ wide. Zones 10-20 $\mu \mathrm{m}$ wide flanking the margines are laevigate or with greatly reduced sculpture. The remainder of the contact areas bear irregularly reticulate ornament with ragged-crested muri up to $7 \mu \mathrm{m}$ high (Figure $8 \mathrm{~K}, \mathrm{M}, \mathrm{O}$ ). Proximal areolae are typically $<20 \mu \mathrm{m}$ in diameter and polygonal to slightly meandroid. The available specimens show great variation in the degree of ornament preservation ranging from pristine to heavily degraded (Figure 8D-I). Curvaturae ridges are essentially positioned equatorially and are developed as a prominent zona $15-25 \mu \mathrm{m}$ wide in inter-radial areas but typically extending up to $35-60 \mu \mathrm{m}$ or locally to $100 \mu \mathrm{m}$ wide as short auriculae in radial areas (Figure 8E, H, K). Distal ornament consists of more regularly polygonal muri $5 \mu \mathrm{m}$ wide and $10 \mu \mathrm{m}$ high encircling areolae $40-70 \mu \mathrm{m}$ in diameter (Figure $8 \mathrm{~N}$ ). Junctions of muri commonly extending to form $40 \mu \mathrm{m}$ high coni. Spore wall composed of spongy meshwork of sporopollenin (Figure 8M, N). Sparse, elliptical, scabrate, possibly monolete microspores, up to $50 \mu \mathrm{m}$ long and $40 \mu \mathrm{m}$ wide, occur trapped in the coarse ornament of some megaspores (Figure 8L).

Remarks. - Minerisporites patagonicus Archangelsky et Villar de Seoane, 1989, M. laceratus Archangelsky

Figure 5. A-K. Trileites sp. cf. T. pinguis: A. Distal view showing laevigate surface, LO11819t; B. Distal view showing laevigate surface, LO11820t; C. Broken proximal region of megaspore with smooth inner surface, LO11821t; D. Megaspore in equatorial view with hemispherical proximal and distal surfaces, LO11822t; E. Detail of laevigate distal surface, LO11819t; F. Broken wall of megaspore showing granular structure, LO11821t; G. Proximal surface of megaspore showing low, narrow laesurae, NRM S089648; H. Enlargement of laevigate surface showing microporous structure, NRM S089661; I. Cross-section of megaspore wall showing granular structural elements, NRM S089650; J. Proximal surface of megaspore showing low, narrow laesurae, NRM S089651; K. Details of equatorial limit of laesura showing isolated flanking granules, NRM S089651. Scale bars - $100 \mu \mathrm{m}(\mathrm{A}-\mathrm{D}, \mathrm{G}, \mathrm{J}, \mathrm{K}), 10 \mu \mathrm{m}(\mathrm{E}, \mathrm{F}, \mathrm{H}, \mathrm{I})$.

Figure 6. A-L. Trileites sp. cf. T. subdeltoides: A. Distal surface, NRM S089600; B. Distal surface, NRM S089553; C. Proximal surface, NRM S089589; D. Details of distal surface, NRM S089600; E. Details of distal surface, NRM S089553; F. Enlargement of proximal surface showing apiculae near the polar region of a contact area, NRM S089589; G. Details of marginal area of proximal surface, NRM S089591; H. Hemispherical distal surface, NRM S089603; I. Details of proximal surface, NRM S089567; J. Proximal surface, details of small mamillae of contact area, NRM S089589; K. Equatorial view of compressed megaspore, NRM S089567; L. Equatorial view of compressed megaspore, NRM S089595. Scale bars - $100 \mu \mathrm{m}$ (A-C, H, K, L), $10 \mu \mathrm{m}$ (D-G, I, J). 

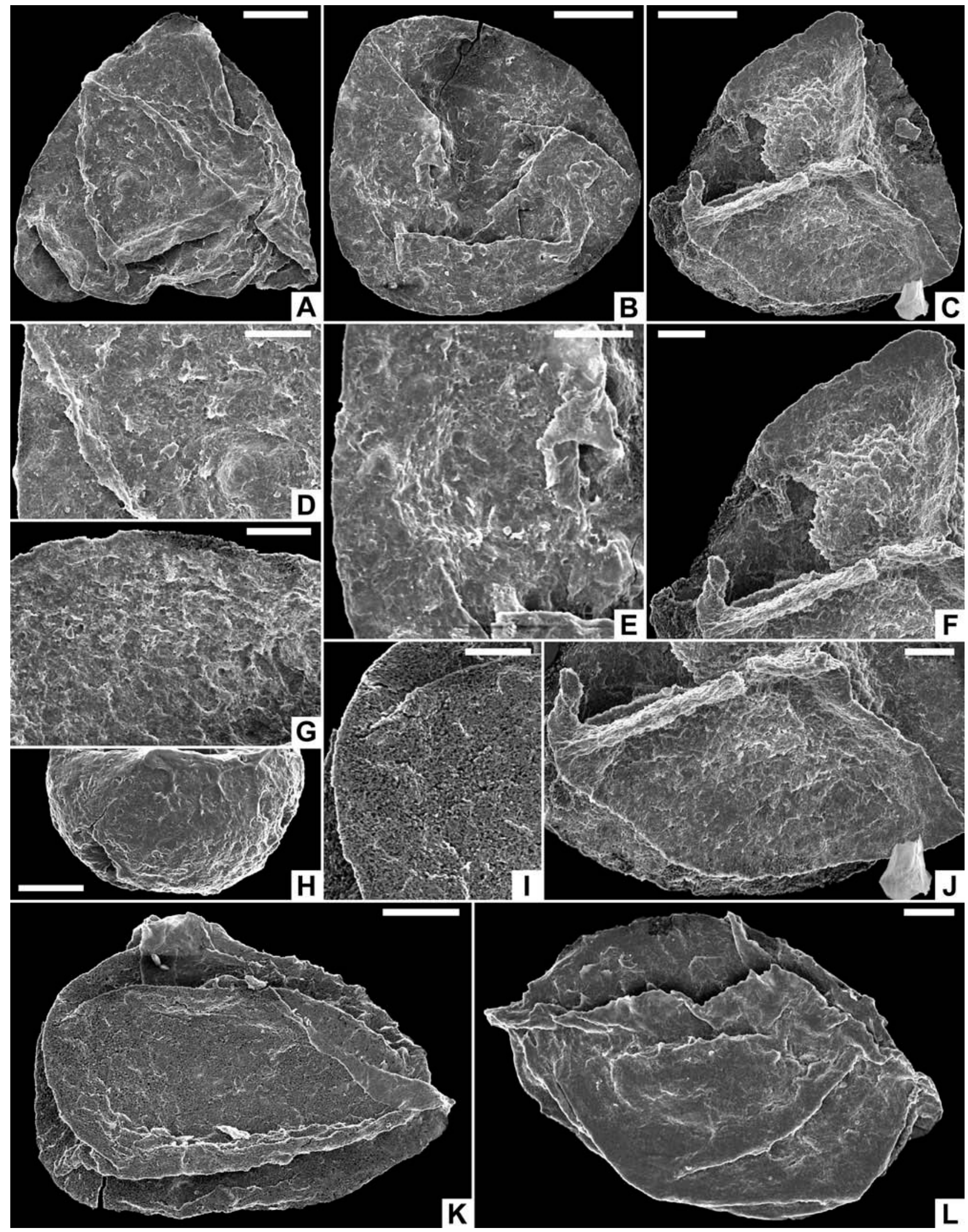


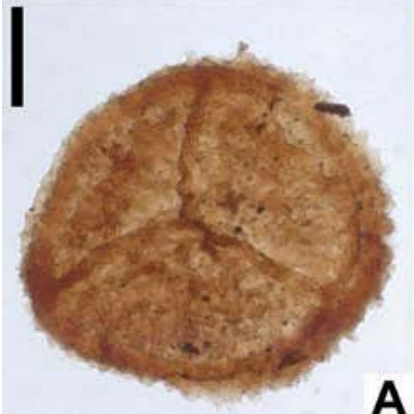

1
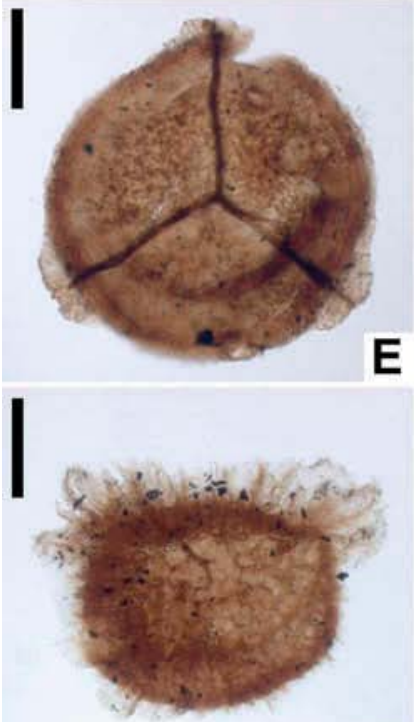

I

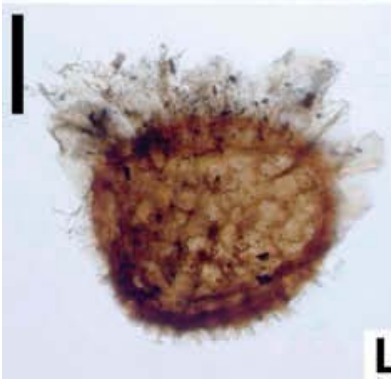

A

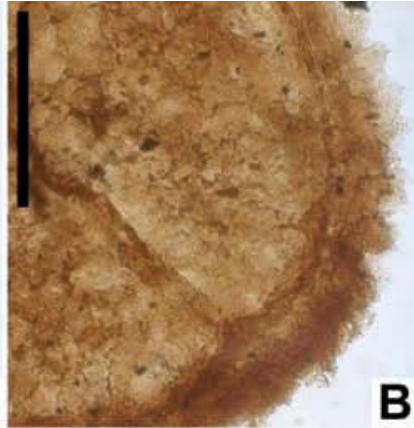

B

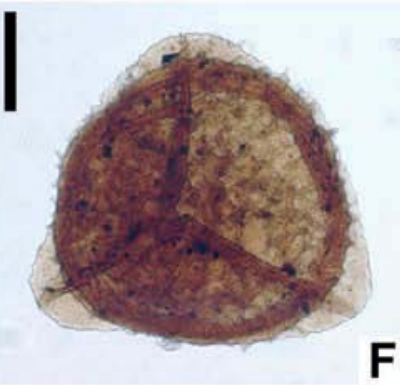

$\mathbf{F}$
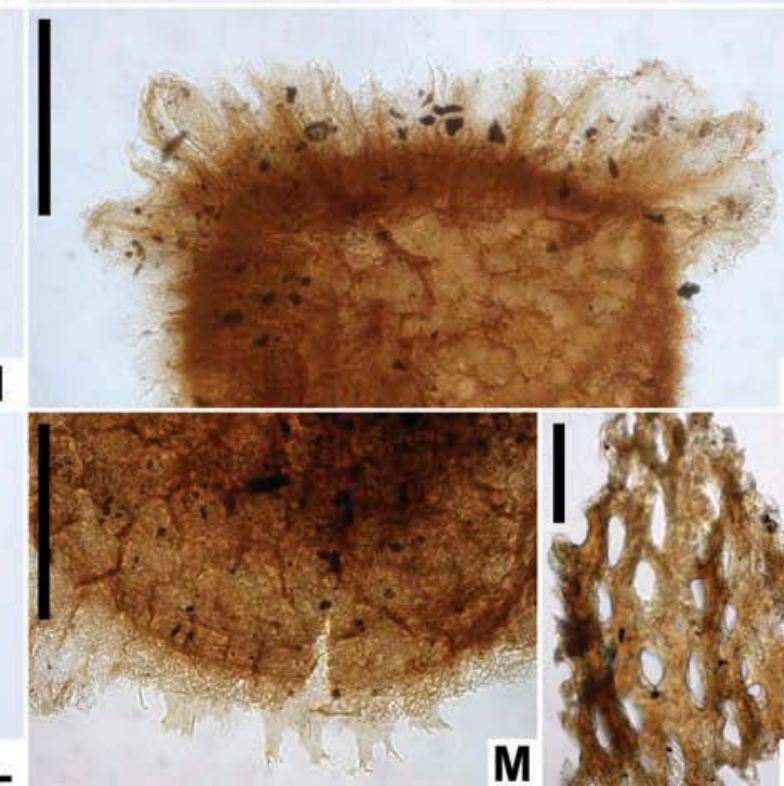

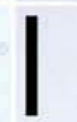
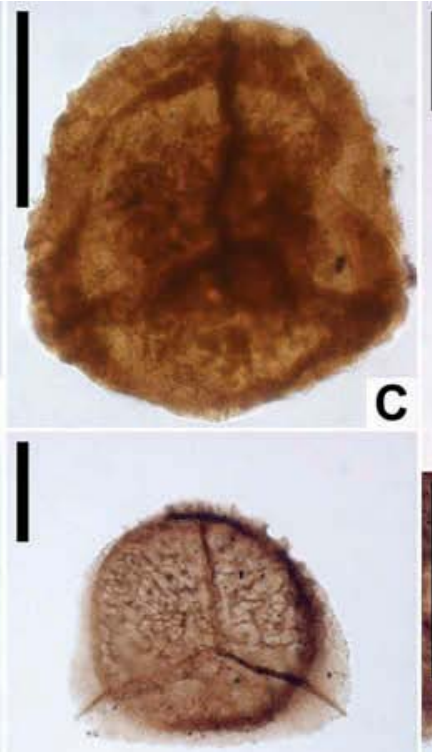

G

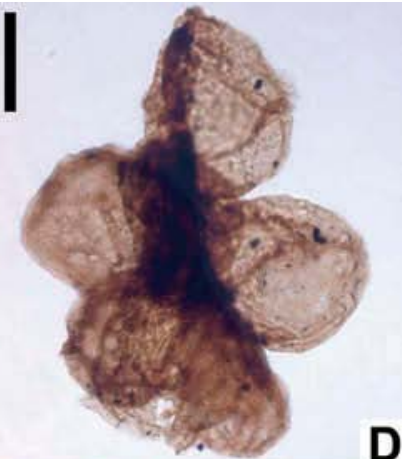

D

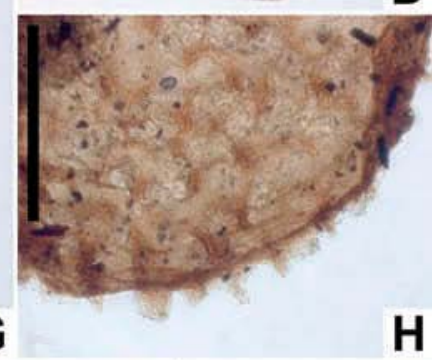

J
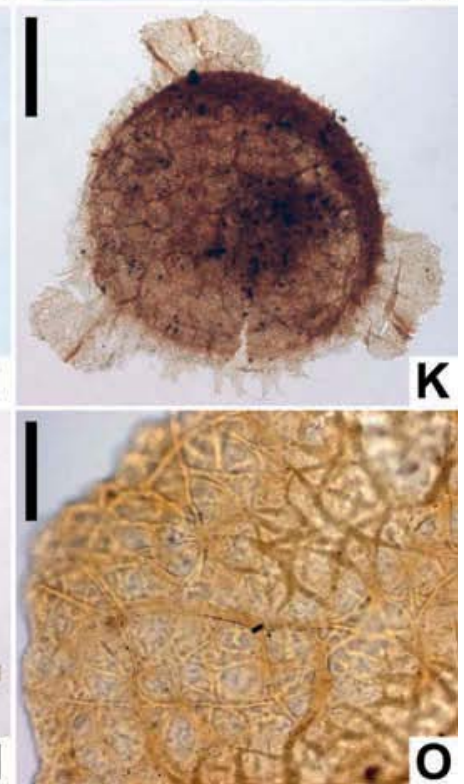

Figure 7. Light micrographs of megaspores and clitellate annelid egg cases from the Marburg Subgroup at Inverleigh. A-C. Horstisporites sp. cf. H. microlumenus: A. Polar view; B. Enlargement of contact area, NRM S089674-01; C. Polar view, NRM S089683. D. Trileites sp. cf. T. subdeltoides, cluster of immature megaspores, NRM S089684-01. E-G. Minerisporites alius, polar view, NRM S089673-01 (E), S089674-02 (F), S089673-02 (G). H-M. Paxillitriletes rainei sp. nov.: H. Distal ornament, NRM S089676-01; I. Equatorial view; J. Proximal ornament, NRM S089675; K. Distal view showing prominent auriculae, NRM S089676-02; L. Equatorial view, NRM S089682; M. Enlargement of equatorial ornament, NRM S089676-02. N. Dictyothylakos pesslerae, NRM S089674-02. O. Burejospermum crassitestum, showing densely amalgamated filamentous secretions, NRM S089672. Scale bars $-100 \mu \mathrm{m}$.

et Villar de Seoane, 1990 and allied forms (Tosolini et al., 2002), all common in the Southern Hemisphere Early Cretaceous, have more regularly reticulate ornamentation with broader muri (in some cases the muri extending onto the zona) than the Jurassic specimens described here. Although the Inverleigh specimens show substantial variation in the development of the sculpture, we find no distinctive characters that permit consistent differentiation from $M$. alius originally described from the Early Cretaceous of England. Minerisporites auriculatus Singh, Srivastava et Roy, 1964, M. cutchensis Singh, Srivastava et Roy, 1964 and M. mineri (Sukh Dev) Banerji, Jana et Maheshwari, 1984 from the Early Cretaceous of western India also have broadly similar morphology but appear to have less 

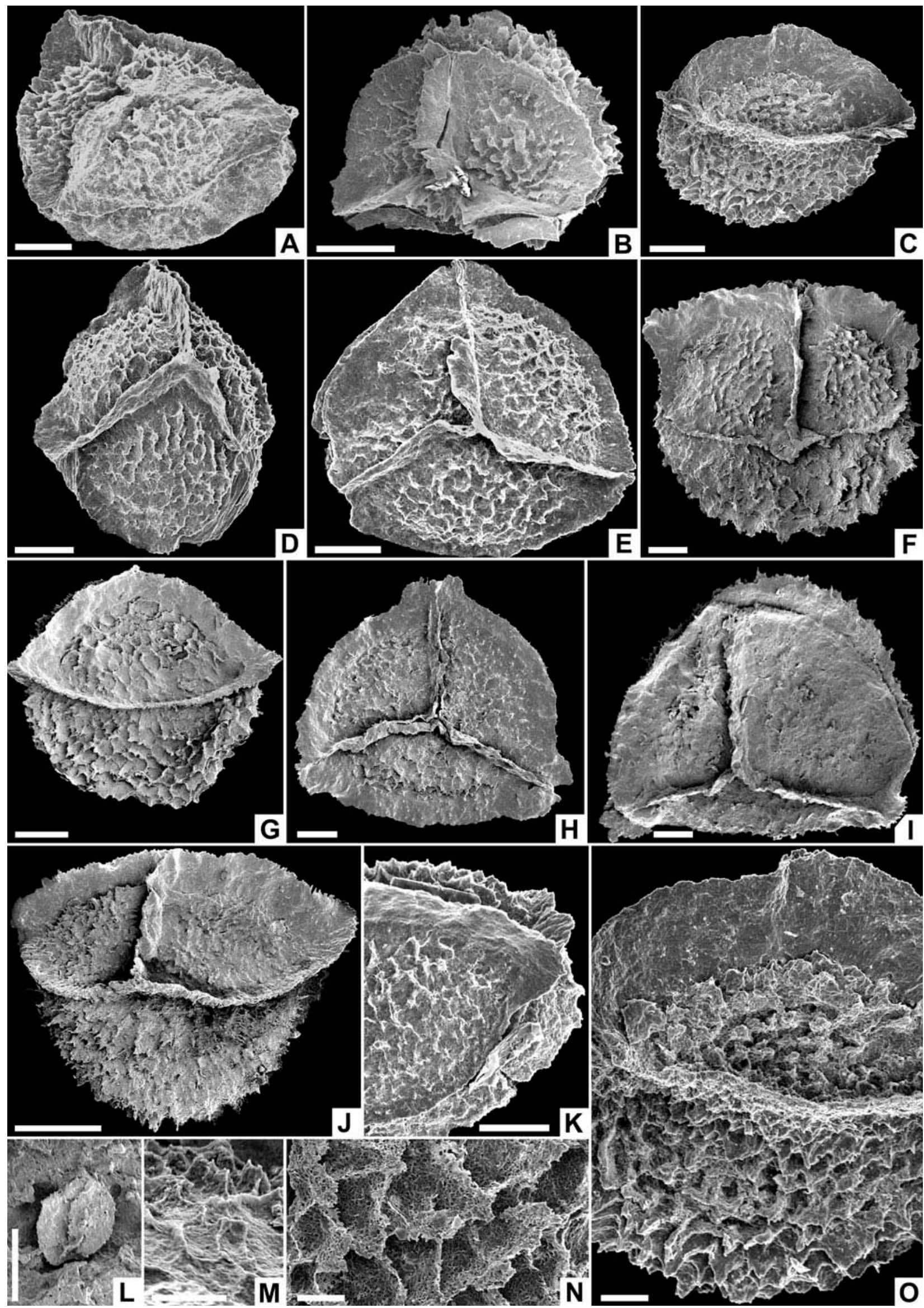

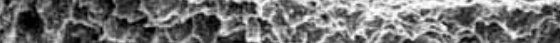

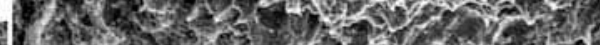
- 5. 20 .

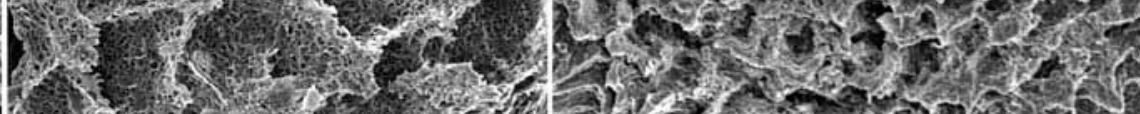
6. 12 .

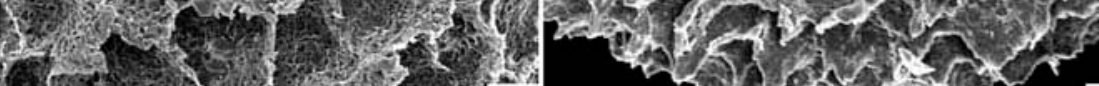
N

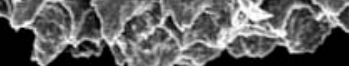


pronounced projections at the muri junctions. There is considerable intraspecific variation in the width of the zona, diameter of the areolae, prominence of the muri, and development of spines at the muri junctions within the Inverleigh population (Figure 8A-I). Based on this variation, we suspect that where several taxa of Minerisporites have been differentiated on subtle differences in these characters from a single assemblage, these megaspores probably represent morphologically variable forms derived from a common parent plant (see, e.g. several species of this genus differentiated by Singh et al., 1964). Examples of small clustered megaspores attributed to $M$. reticulatus (Singh, Srivastava et Roy) Banerji, Jana et Maheshwari, 1984 by Jana and Ghosh (1997) are notably similar to diminutive, thin-walled examples of $M$. alius in the present collection. These may represent immature forms macerated from sporangia that have not yet developed well-defined ornamentation or zonae. Sparse examples of scabrate, ?monolete microspores, c. $25 \mu \mathrm{m}$ in diameter, are attached to the surfaces of these megaspores (Figure 8L) and entrapment in the ornamentation may represent a strategy for more successful gamete transfer (Slater et al., 2011). Similar-sized, scabrate, monolete microspores have been found attached to other species of Minerisporites (e.g. Collinson, 1991, figure 7.3; Batten \& Collinson, 2001, pl. 1, figures 1, 10), and this consistent link appears to reflect a true biological association.

\section{Minerisporites $s p . A$}

(Figure 9A, C)

\section{Material. - LO11826t.}

Description. - Convexly subtriangular megaspore, compressed, only available in proximal view; $465 \mu \mathrm{m}$ in equatorial diameter. Margines prominent, consistently around $20 \mu \mathrm{m}$ high and narrow ( $<5 \mu \mathrm{m}$ wide). Laesurae extending almost to equator. Equatorial ends of margines linked by curvaturae ridges that are prominent initially but decrease in height and become ill-defined in inter-radial areas (Figure 9A). Narrow (c. $20 \mu \mathrm{m}$ wide) zones flanking the margines and curvaturae ridges are free of ornament. Otherwise, the contact areas bear variable ornament: some areas bearing basally abutting verrucae and coni, locally with lobed or bifid tips up to $25 \mu \mathrm{m}$ high and wide; other areas bearing a low reticulum with weakly developed coni at muri junctions (Figure 9C). Ornament becoming generally finer and less dense from the pole to equator. Distal ornament predominantly of coni $15-20 \mu \mathrm{m}$ in height and basal diameter.

Remarks. - The single available specimen has some similarities to various Minerisporites species in its ornament-free zones flanking the laesurae but the typical ornament of verrucae or truncate to lobed coni is distinct. Given the variability in its ornament between contact areas, the spore may be an aberrant form of Minerisporites alius described earlier. However, we retain it as a separate informal taxon pending discovery of a larger population of specimens.

Minerisporites sp. $c f$. M. labiosus Baldoni et Taylor, 1985

(Figure 10E)

\section{Material. — NRM S089579, NRM S089605.}

Description. - Megaspore with subtriangular amb; $200-450 \mu \mathrm{m}$ in equatorial diameter; polar diameter c. $300 \mu \mathrm{m}$; radial areas rounded or only slightly protruding. A zona up to $35 \mu \mathrm{m}$ is developed. Laesurae slightly wavy, persisting to equator. Margines narrow and up to $50 \mu \mathrm{m}$ high with generally smooth crests. Proximal surface with scabrate texture, or locally with ill-defined irregular coni up to $20 \mu \mathrm{m}$ high, or in some places composed of an irregular network of spongy threads (Figure 10E). Distal ornament scabrate.

Remarks. - Only two specimens were identified one illustrated by SEM (Figure 10E). Both Minerisporites labiosus of Baldoni and Taylor (1985) and Minerisporites sp. cf. M. marginatus of

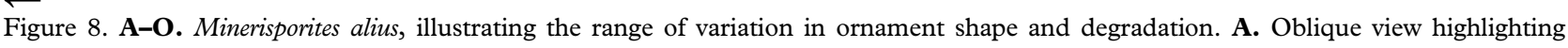
contact area, NRM S089556; B. Proximal surface showing prominent flanges flanking contact areas, NRM S089561; C. Equatorial view showing pyramidal proximal surface and hemispherical distal surface, NRM S089578; D. Proximal surface, NRM S089558; E. Proximal surface with weakly developed auriculae, NRM S089557; F. Equatorial (radial) view, LO11823t; G. Equatorial (inter-radial) view, NRM S089644; H. Proximal view, LO11824t; I. Proximal view with heavily degraded ornament, LO11825t; J. Equatorial view showing spinose tufts developed on the junctions of some muri on the distal surface, NRM S089647; K. Enlargement of equatorial area showing development of weak auriculum, NRM S089607; L. Enlargement of folded scabrate microspore attached to megaspore surface, NRM S089662; M. Enlargement of reticulate/tufted proximal ornament, NRM S089598; N. Enlargement of distal ornament, NRM S089594; O. Enlargement of ornament in equatorial view, NRM S089578. Scale bars - $100 \mu \mathrm{m}(\mathrm{A}-\mathrm{K}), 10 \mu \mathrm{m}(\mathrm{L}-\mathrm{O})$.
} 

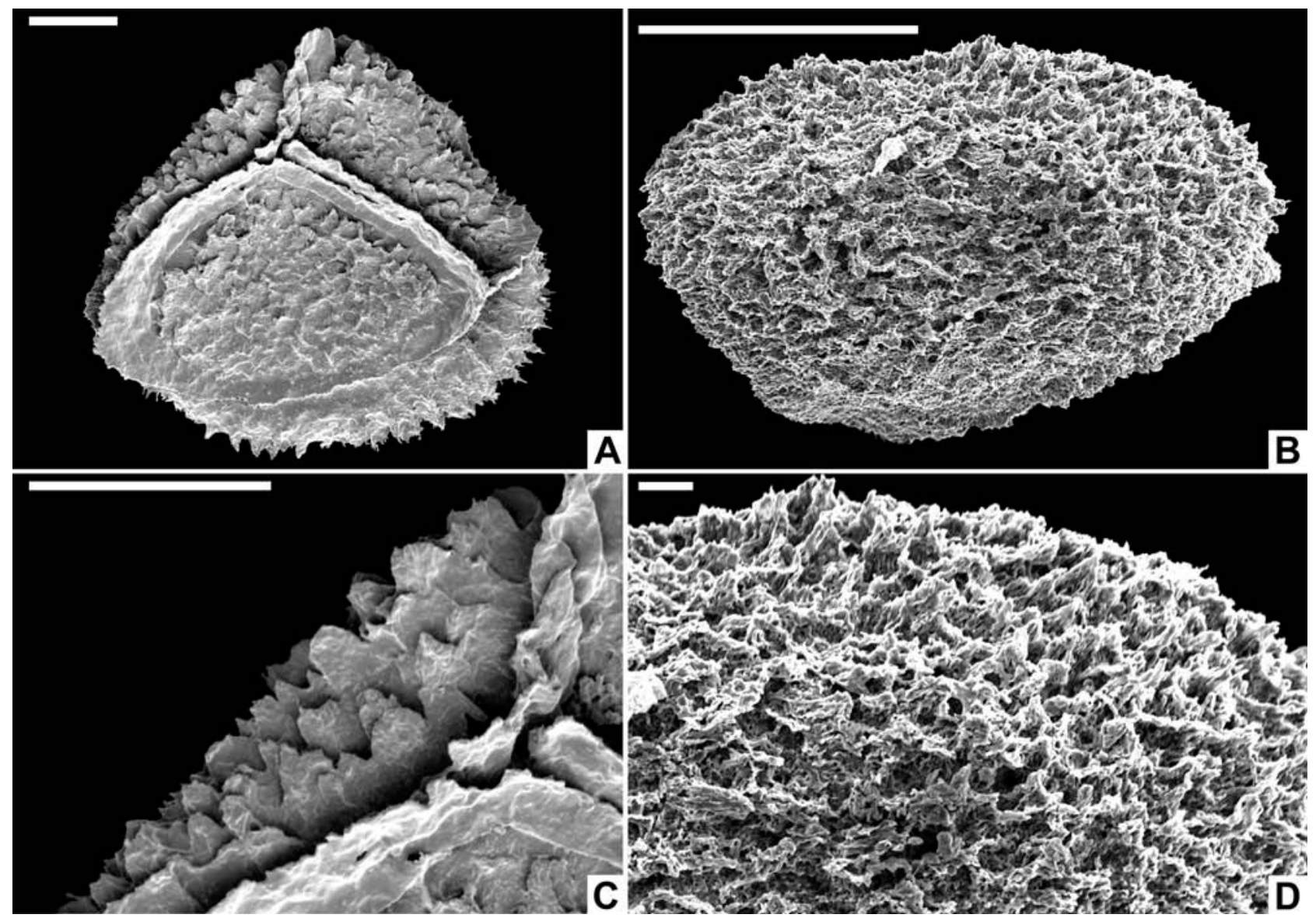

Figure 9. A, C. Minerisporites sp. A, LO11826t: A. Proximal surface; C. Enlargement of coni and verrucae on the contact area. B, D. Horstisporites sp. cf. H. microlumenus, NRM S089584: B. Distal surface; D. Details of tufted ornament. Scale bars - $100 \mu \mathrm{m}$ (A-C), $10 \mu \mathrm{m}$ (D).

Baldoni and Batten (1991) from the Lower Cretaceous of Argentina are similar to these Inverleigh specimens in their generally scabrate ornament and weakly developed zona, although muri are more clearly developed on the Argentinean forms. It is conceivable that the specimens are degraded examples of $M$. alius described earlier but, pending the collection of a more representative population of megaspores, we retain them under Minerisporites sp. cf. M. labiosus based on their scabrate appearance.

Horstisporites Potonié, 1956

Type species. - Horstisporites reticuliferus (Dijkstra) Potonié, 1956; ?Berriasian-Valanginian, The Netherlands.

Horstisporites sp. $c f$. H. microlumenus Dettmann, 1961

(Figures 7A-C, 9B, D)

Material. — NRM S089674-01, NRM S089584.
Description. - Megaspore with convexly subtriangular, circular or elliptical amb (Figure 7A, C), 200-235 $\mu \mathrm{m}$ in maximum equatorial diameter. Laesurae extending to equator, slightly sinuous, flanked by narrow margines up to $20 \mu \mathrm{m}$ high. Curvaturae ridges, $20 \mu \mathrm{m}$ high, enclose contact areas and link the equatorial ends of margines. Contact areas with irregular reticulate ornamentation of low ridges and folds (Figure 7B). Areolae generally $<16 \mu \mathrm{m}$ in diameter. Muri extending slightly onto curvaturae ridges. Distal ornament consisting of complex reticulum with areolae up to twice the diameter of those on the proximal surface (Figure 9B). Where well preserved, the muri are c. $3 \mu \mathrm{m}$ wide, of irregular height, tufted at the junctions, with lacerate peaks reaching $10 \mu \mathrm{m}$ high (Figure 9D). Areolae locally incomplete and forming meandroid troughs. Spore wall strongly porous and formed of interlocking fibrous vermiform structural elements.

Remarks. - This form is similar in its relatively dense but irregularly reticulate sculpture to 

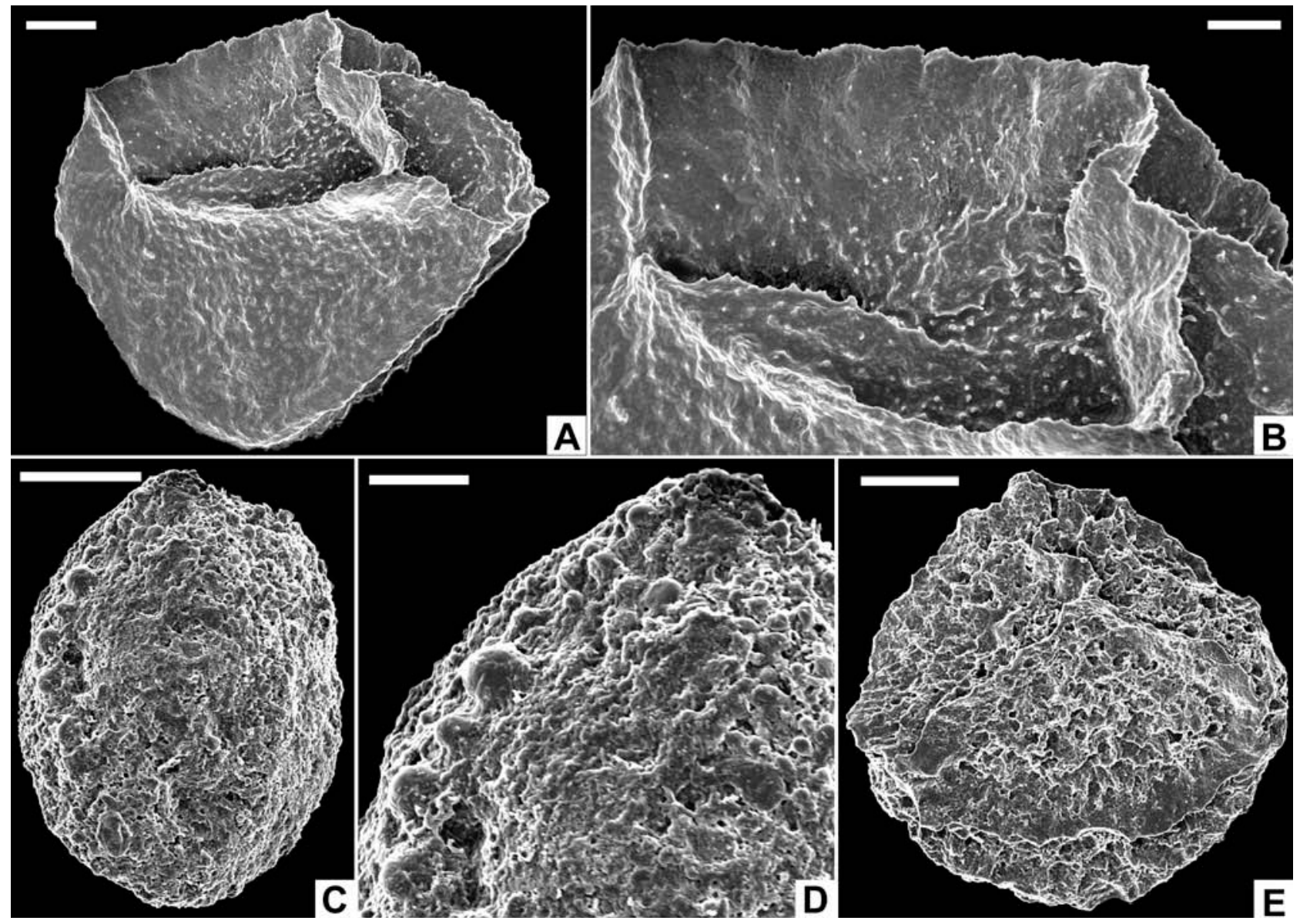

Figure 10. A, B. Scabratriletes sp., NRM S089580: A. Equatorial view; B. Enlargement of ornament on contact area and equatorial region of distal surface. C, D. ?Cabochonicus sp., NRM S089572: C. Oblique view; D. Enlargement of ornament. E. Minerisporites sp. cf. M. labiosus, NRM S089605, proximal surface of megaspore with irregularly ornamented surface. Scale bars - $100 \mu \mathrm{m}$ (A, C, E), $10 \mu \mathrm{m}$ (B, D).

Horstisporites microlumenus described from the Upper Triassic of Tasmania. The Inverleigh specimens differ in being only slightly smaller than the size range of the species outlined by Dettmann (1961). Srivastavaesporites crassus Pant and Mishra, 1986 from the Permian of India has short irregular ornament described by the original authors as verrucae but probably also including short coni of similar dimensions to the tufted muri junctions of the Inverleigh specimens, though the sculptural elements are more widely spaced on the Indian specimens.

Paxillitriletes Hall et Nicholson emend. Batten et Koppelhus, 1993

Type species. - Paxillitriletes reticulatus (Mädler) Hall et Nicholson, 1973; Berriasian, Germany.

Paxillitriletes rainei McLoughlin, fansson et Vajda sp. nov.

(Figures $7 \mathrm{H}-\mathrm{M}, 11 \mathrm{~A}-\mathrm{H}$ ) cf. 1975 Paxillitriletes phyllicus (Murray) Hall et Nicholson, 1973; Filatoff, 1975, p. 55-56, plate 8 , figures 8,9 .

Etymology. - After New Zealand palynologist Ian Raine, who has had a distinguished career working on Gondwanan Mesozoic and Cenozoic palynofloras.

Holotype. NRM S089652 (Figure 11C, D, H).

Type unit, age and locality. - Undifferentiated Marburg Subgroup; late Pliensbachian; Inverleigh Quarry, Clarence-Moreton Basin, Australia.

Material. - LO11827t, LO11828t, NRM S089552, NRM S089643, NRM S089652, NRM S089663.

Diagnosis. - Paxillitriletes with prominent auriculate radial extensions; inter-radial areas bearing a weakly defined zona or ridge; laesurae extending onto auriculae; margines reaching $100 \mu \mathrm{m}$ high, with lacerate 

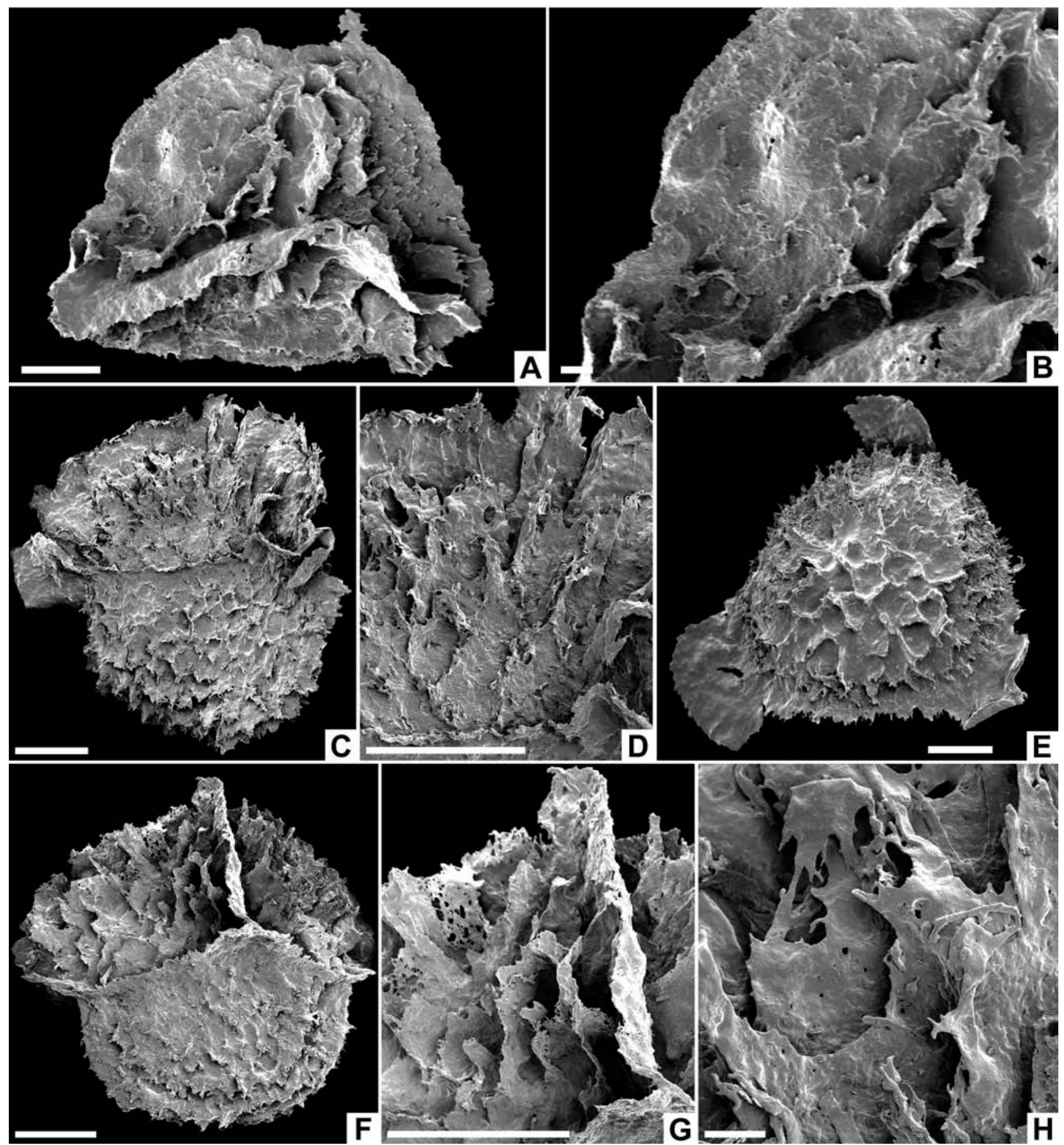

Figure 11. Paxillitriletes rainei sp. nov. A, B. Somewhat degraded megaspore, LO11827t: A. Proximal surface; B. Enlargement of ornament. C, D, H. Megaspore, NRM S089652 (holotype): C. Equatorial view; D. Enlargement of proximal ornament and flange-like margo; $\mathbf{H}$. Enlargement of proximal lacerate sculptural elements. E. Distal view of megaspore showing prominent auriculae, LO11828t; F, G. Megaspore in equatorial view with enlargement of flange-like margo (G), NRM S089643. Scale bars - $100 \mu \mathrm{m}(\mathrm{A}, \mathrm{C}-\mathrm{G}), 10 \mu \mathrm{m}(\mathrm{B}, \mathrm{H})$.

crests and lateral buttresses; ornament adjacent to laesurae forming tall and broad furcate or lacerate flanges. Junctions of muri on distal surface spinose.

Description. - Megaspore with convexly subtriangular to circular amb with prominent auriculate radial extensions (Figures $7 \mathrm{~K}, 11 \mathrm{E}$ ); equatorial diameter 360-
$530 \mu \mathrm{m}$, polar diameter c. $400 \mu \mathrm{m}$. Distal side hemispherical, proximal side a low dome. Laesurae straight or slightly wavy, extending onto auriculae (Figure 11A, E). Margines very prominent, reaching $100 \mu \mathrm{m}$ high, with lacerate crests and bearing $20 \mu \mathrm{m}$ diameter spines and buttresses (Figures 7I, J, L, 11G). Proximal surface with reticulum of $5 \mu \mathrm{m}$ wide muri enclosing 
polygonal areolae 10-30 $\mu \mathrm{m}$ in diameter (Figure 11D). Ornament adjacent to laesurae expanded into large furcate or lacerate flanges up to $80 \mu \mathrm{m}$ high and $25 \mu \mathrm{m}$ wide (Figure 11G, H). Equator marked by auriculae up to $100 \mu \mathrm{m}$ in radial length, inter-radial areas marked by a weakly defined zona or ridge, locally with lacerate projections (Figure $7 \mathrm{M}$ ). Distal surface bearing robust reticulate ornament with muri up to $10 \mu \mathrm{m}$ wide enclosing polygonal areolae up to $60 \mu \mathrm{m}$ in diameter. Junctions of muri locally extended into spines up to $15 \mu \mathrm{m}$ high (Figure $7 \mathrm{H}$ ). Surface between major sculptural elements essentially smooth.

Remarks. - Many specimens of this species in the Inverleigh assemblages are strongly damaged suggesting fragility or a greater degree of transport compared to other megaspore types. Furthermore, most are equatorially compressed, making views of the complete proximal surface difficult to obtain. Some specimens with degraded ornament have ragged ridge-like sculptural elements flanking the margines and abraded auriculae (Figure 11A, B) making them similar to Minerisporites species. Better-preserved specimens with prominent auriculae, weakly defined zona, well-developed reticulum on both distal and proximal surfaces, and the very high and ribbed margines have similarities to the relatively broad morphological variation represented by $M$. richardsonii (Murray) Potonié, 1956 emend. Harris, 1961. However, that species, mostly known from the Pliensbachian-Hauterivian of Europe (Koppelhus \& Batten, 1992), lacks the very elaborate ornament adjacent to the margines evident on well-preserved Paxillitriletes rainei specimens. Specimens assigned to Thomsonia sp. cf. T. reticulata Mädler, 1954, Dijkstraisporites sp. of Sukh Dev (1961), M. auriculatus, $P$. cutchensis (Singh, Sriva-stava et Roy) Banerji, Jana et Maheshwari, 1984 and P. maheshwariensis Jana et Ghosh, 1997 from the Early Cretaceous of India all bear superficial similarities to $P$. rainei, but differ in one or more characters of the auriculae development, zona width, or proximal ornament shape. The only previously illustrated Jurassic megaspore from Australia, attributed to $P$. phyllicus (Murray) Hall et Nicholson, 1973 (Filatoff, 1975, plate 8, figures 8, 9) likely belongs to $P$. rainei, although the apical shape of its very robust proximal ornament is not clear. The type material of $P$. phyllicus differs from $P$. rainei in having more leaf-like and fused proximal sculptural elements (Murray, 1939, text-figures 7,8 ).

Scabratriletes Van der Hammen ex Potonié, 1956

Type species. - Scabratriletes cristatus (Dijkstra) Potonié, 1956; Santonian, The Netherlands.
Scabratriletes $s p$.

(Figure 10A, B)

\section{Material. - NRM S089580.}

Description. - Megaspore with hemispherical distal surface and low pyramidal proximal surface; $150 \mu \mathrm{m}$ in equatorial diameter and $315 \mu \mathrm{m}$ in polar diameter. Laesurae straight to slightly wavy. Margines with smooth or slightly undulate crests, $5 \mu \mathrm{m}$ wide and up to $40 \mu \mathrm{m}$ high at the pole, decreasing in height slightly but persisting to equator (Figure 10A). Tips of margines linked by prominent curvaturae ridges up to $10 \mu \mathrm{m}$ high and $5 \mu \mathrm{m}$ wide (Figure 10A). Contact areas with sparse and irregularly arranged grana to low apiculae ( $<2 \mu \mathrm{m}$ high and in basal diameter) that locally extend with reduced size and abundance onto the flanks of the margines. Distal surface with granulate to weakly apiculate ornamentation (Figure 10B).

Remarks. - This form has a distal texture similar to that of Maexisporites soldanellus (Dijkstra) Potonié, 1956 but less densely ornamented contact areas bounded by more prominent curvaturae ridges and margines (see also Koppelhus \& Batten, 1992, plate 11, figures 3-8). ? Maexisporites sp. of $\mathrm{Li}$ et al. (1987) has broadly similar granulate ornament but the elements are larger and better developed on the proximal surface. Both Henrisporites heteracanthus Gamerro, 1975 from the Early Cretaceous of Argentina and Verrutriletes sp. cf. V. papillosus (Miner) Potonié, 1956 illustrated by Batten (1995) from the Aptian of northern Germany have roughly similar ornament but less pronounced margines than the specimens described here. Scabratriletes cristatus from the Late Cretaceous of the Netherlands appears to be most similar morphologically to these Inverleigh specimens, although the former has sculptural elements that are slightly more robust and that extend to the crests of the prominent margines (Batten, 1988).

?Cabochonicus $s p$.

(Figure 10C, D)

\section{Material. — NRM S089572.}

Description. - Ellipsoidal megaspore, only observed in distal view (i.e. apparently mounted on its proximal face); $181 \mu \mathrm{m}$ in greatest dimension, $128 \mu \mathrm{m}$ in narrowest dimension. Surface irregularly ornamented with broadly rounded gemmae or verrucae reaching a maximum of $11 \mu \mathrm{m}$ high and $12 \mu \mathrm{m}$ wide (average $2.5 \mu \mathrm{m}$ high and wide, Figure 10C). One prominent 
impersistent row of large gemmate elements present (Figure 10D) but this does not appear to demarcate a contact area or define the position of laesurae. Areas between the major sculptural elements are ornamented by low mounds and wrinkles (Figure 10D).

Remarks. - A single small specimen is available. The surface ornament is variable and possibly degraded. The presence of a few large gemmate sculptural elements invokes similarities to species of Cabochonicus (see e.g. Batten, 1988; Koppelhus \& Batten, 1989, 1992; Archangelsky \& Villar de Seoane, 1991; Cantrill \& Drinnan, 1994), but the absence of available details of the proximal surface on the single specimen prevents detailed comparisons with other species. The generally rough surface of the megaspore between the major gemmae is atypical of Cabochonicus species, which are generally laevigate between the dominant sculptural elements. The single specimen may also be a small aberrant form of Trileites sp. cf. T. pinguis (described earlier), which in a few cases has small spherical sculptural elements (grana) near the laesurae (Figure 5K). Finally, it cannot be excluded that this small ellipsoidal mesofossil represents a minute invertebrate coprolite composed of dense amorphous matter (cf. examples illustrated by McLoughlin et al., 2002; Tosolini \& Pole, 2010; Slater et al., 2012).

\section{Leaf fragments}

Remarks. - Assorted cuticle fragments occur throughout the mesofossil assemblages. Some have distinctive dentate margins and are attributable to the putative araucariacean Allocladus helgei Jansson in Jansson et al. (2008b). Other small cuticle fragments with non-diagnostic characters in the assemblage may derive from other gymnosperms documented from this locality, e.g. Sagenopteris and Rintoulia (Jansson et al., 2008b) or to a range of other pteridosperms and conifers known elsewhere in the host unit (Gould, 1971).

Seed

(Figure 12A, B)

\section{Material. — LO118294t.}

Description. - Platyspermic elliptical seed, $2.1 \mathrm{~mm}$ long, $1.8 \mathrm{~mm}$ wide, with a rounded base, broken apex, and $0.25 \mathrm{~mm}$ wide low median ridge that decreases in width towards the apex (Figure 12A). Surface ornamented with very fine $(8-10 \mu \mathrm{m}$ wide) very low longitudinal ridges, $10-15 \mu \mathrm{m}$ apart, which persist over hundreds of micrometres (Figure 12B).

Remarks. - This seed is illustrated to complement the diversity of gymnosperm remains documented from this site by Jansson et al. (2008b). The single available seed cannot be attributed confidently to a particular plant group.

\section{Arthropod fragment}

(Figure 12C, D)

\section{Material. — NRM S089550.}

Description. - Arthropod exoskeleton fragment $200 \mu \mathrm{m}$ long with prominent, although commonly broken, spines arranged in loose linear-curvilinear ranks (Figure 12C). Spines are up to $95 \mu \mathrm{m}$ long, $5 \mu \mathrm{m}$ wide and are separated by $c .16-25 \mu \mathrm{m}$ within rows and c. $30 \mu \mathrm{m}$ between rows. Spines are set in

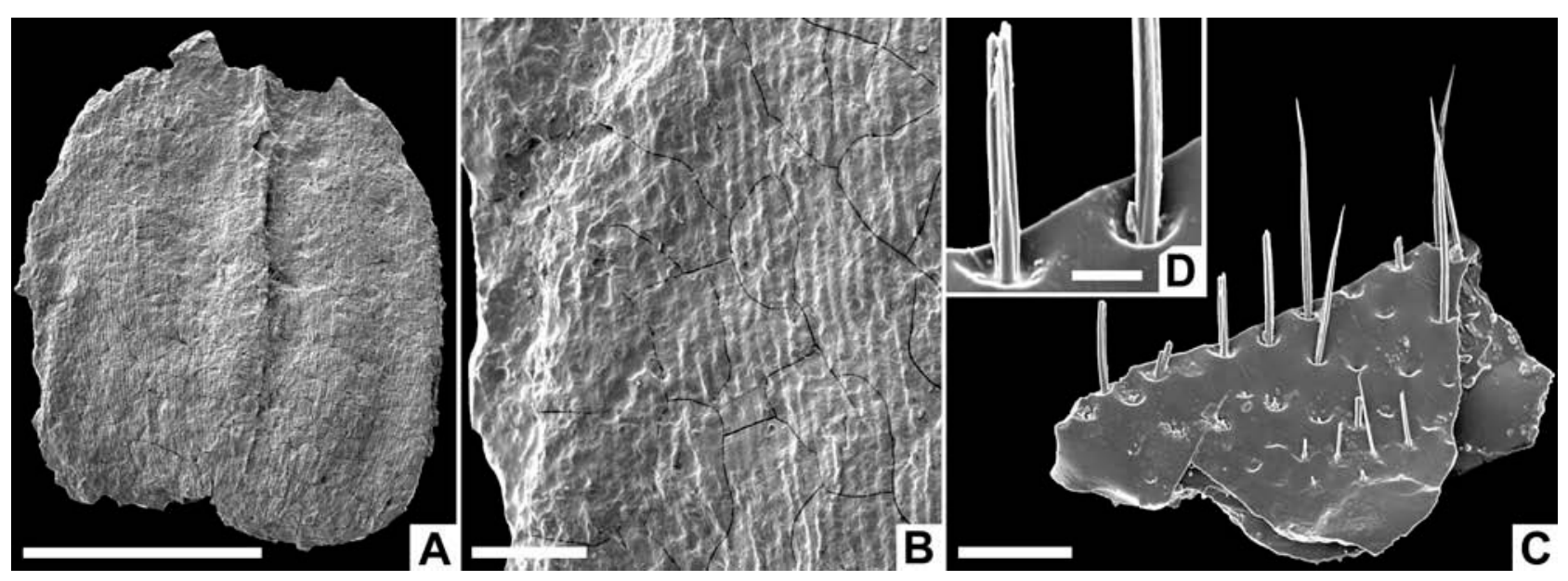

Figure 12. Other mesofossils associated with megaspores. A, B. Seed, LO11829t: A. lateral view; B. Enlargement of seed surface with striate ornament. C, D. Arthropod exoskeleton fragment with enlargement of tri-filamentous spines (D), NRM089550. Scale bars - 1 mm (A), $100 \mu \mathrm{m}(\mathrm{B}, \mathrm{C}), 10 \mu \mathrm{m}(\mathrm{D})$. 
shallow cup-like depressions $c .10 \mu \mathrm{m}$ in diameter (Figure 12D). Spines consist of three fused filaments, with grooves marking the line of fusion; spines taper to a sharp tip. The surface texture of the exoskeleton plate between the spines is smooth or very weakly wrinkled.

Remarks. - Spinose exoskeleton fragments are common constituents of mesofossil assemblages of all ages since the late Palaeozoic (McLoughlin et al., 1997; Batten, 1998; Montoya et al., 2012; Slater et al., 2012). Most examples, including those from Inverleigh, cannot yet be confidently ascribed to a particular arthropod group.

\section{Clitellate annelid cocoons}

(Figure 7N, O)

\section{Material. - LO9975t, NRM S089674-02, NRM S089672.}

Remarks. - Two types of clitellate annelid cocoons were recorded and fully described from these strata by Jansson et al. (2008a). Burejospermum crassitestum Krassilov emend. Manum, Bose et Sawyer, 1991 is represented by complete cocoons and detached opercula and was likely produced by hirudineans (Manum et al., 1991). The walls of these structures consist of continuous sheets of densely amalgamated filamentous secretions (Figure 7O). However, the most common fragments recovered in bulk macerations are meshworks of translucent golden-brown wax-like secretions referable to Dictyothylakos pesslerae Horst emend. Manum, Bose et Sawyer, 1991 (Figure $7 \mathrm{~N}$ ). This taxon is widely distributed in continental rocks of Late Triassic to Cenozoic age and may have been produced by hirudineans or oligochaetes (Manum et al., 1991; Tosolini \& Pole, 2010; Bomfleur et al., 2012).

\section{Palynomorphs}

Diversity. - Of the 15 samples processed for palynology (INVA1-4, INVB1-11), 13 were productive (Figure 13) and these host well-preserved and abundant microspores, pollen and fresh-water algae attributable to 59 taxa (Figure 14; Appendix). Spores are the most diverse component incorporating 38 taxa of which 16 are probable fern spores, 16 are lycophyte spores and six are bryophytes. Gymnosperm pollen grains are represented by 18 taxa, and fresh water algae by three. More than $50 \%$ of the samples are dominated by gymnosperm pollen (mainly Classopollis, Araucariacites and Alisporites), whereas the remaining samples are dominated by pteridophyte spores or, in one case, by fresh-water algae. The dominant fern spore genera are Cyathidites, Baculatisporites and Dictyophyllidites. Amongst the lycophytes, Ceratosporites and Retritiletes are most abundant, and amongst the bryophytes Annulispora and Cingutriletes dominate. The composition of the miospore assemblages varies significantly between the samples (Figure 13). Beds near the base of the sampled succession (samples INVA1 and INVB1) contain high relative abundances of freshwater algae including Quadrisporites, Botryococcus braunii Kützing, 1849 and Pediastrum, collectively comprising $83 \%$ of the INVB1 assemblage. Succeeding samples are codominated by gymnosperms and pteridophytes, whilst sample INVB9 near the top of the section is strongly dominated $(83 \%)$ by fern spores (mainly Dictyophyllidites spp., Cyathidites spp. and Foveosporites moretonensis de Jersey, 1964; Appendix). Species diversity also varies significantly between samples, ranging from 8 to 33 taxa per sample (Table II). Sample INVA2 is by far the most taxon-rich, being characterised by diverse gymnosperms, ferns and lycophytes (Table II).

The target group of this study, lycophytes, has an average diversity of 4.2 species per sample (ranging between one species in the algae-dominated INVB1 to eight species in sample INVA2. The relative abundance of lycophyte spores averages c. $10 \%$. The dominant lycophyte taxa in terms of relative abundance are Ceratosporites helidonensis de Jersey, 1971 and Retritiletes spp. Lycophyte abundance peaks at $35.5 \%$ of palynomorphs in sample INVB2 (the most abundant taxon being $C$. helidonensis with lesser representation of Retitriletes rosewoodensis (de Jersey) McKellar, 1974 and R. clavatoides (Couper) Döring et al., 1963).

\section{Discussion}

\section{Age of the assemblage}

The age of the studied succession was interpreted by tying its palynofloral content to the well-resolved miospore zonation scheme of eastern Australia (de Jersey, 1975; McKellar, 1981; Helby et al., 1987; Burger, 1994; de Jersey \& McKellar, 2013) and comparing the spore-pollen suites with coeval northern hemisphere palynological assemblages of Vajda (2001) and Mehlqvist et al. (2009). Based on the high relative abundance of Classopollis, together with relatively high percentages of Cadargasporites reticulatus de Jersey et Paten, 1964 and Dictyophyllidites mortonii (de Jersey) Playford et Dettmann, 1965 and with the presence of Callialasporites spp., we assign the studied assemblage to the Corollina torosa Zone of 

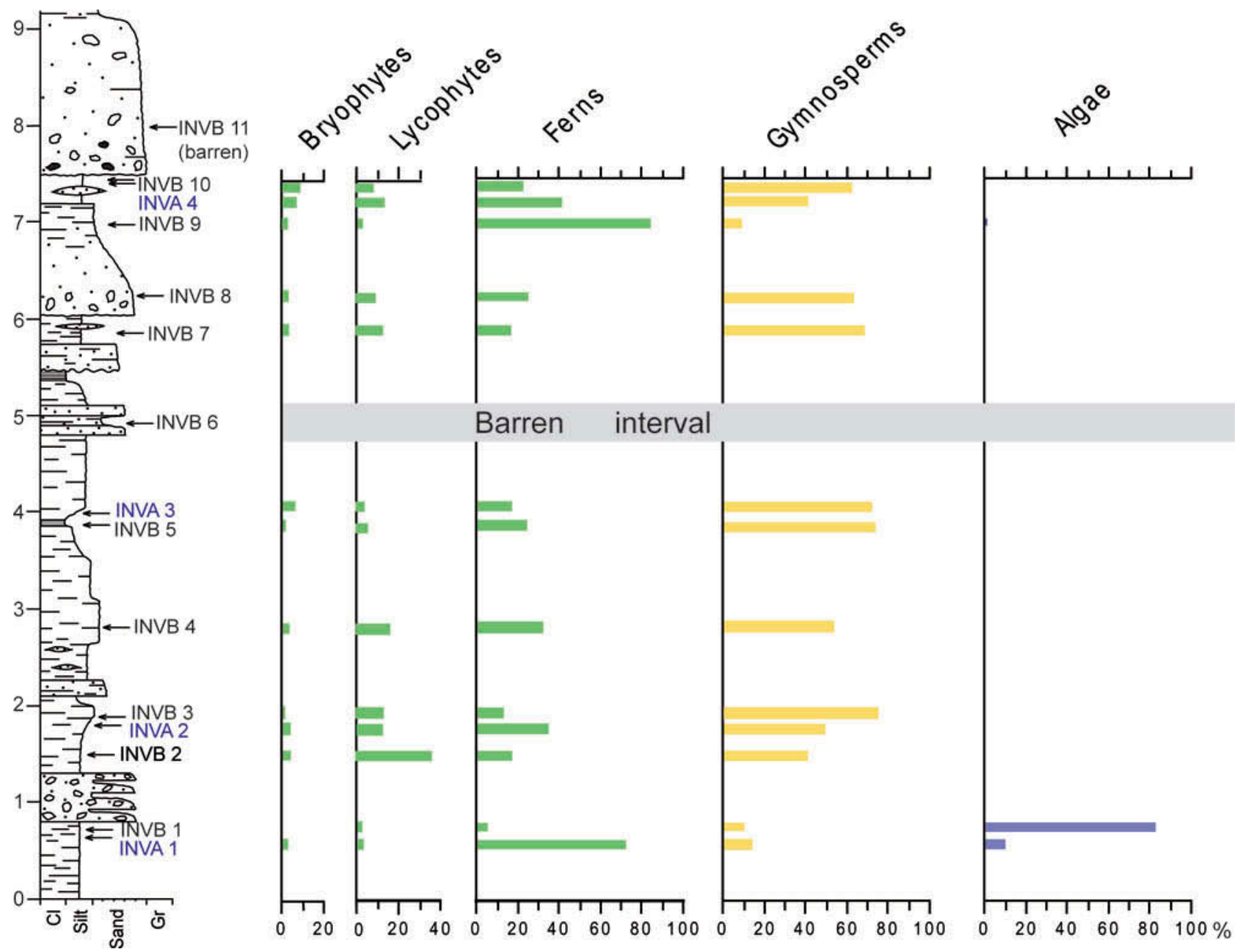

Figure 13. Relative abundance of palynomorphs in samples INVB1-10 from Inverleigh (samples INVA1-4 are those of Jansson, 2008a, 2008b).

Helby et al. (1987), which those authors dated to Pliensbachian-early Toarcian. As pointed out by Helby et al. (1987), the top (Toarcian part) of the Corollina torosa Zone is characterised by relatively high abundances of Callialasporites. In contrast, Callialasporites pollen grains are very rare in the Inverleigh assemblages. Hence, we revise our agedetermination from previous studies (Jansson et al., $2008 a$, 2008b) to assign the Inverleigh succession to the Pliensbachian part of the Corollina torosa Zone.

\section{The megaspore assemblage}

The Southern Hemisphere is greatly under-represented in terms of both number of recorded species and publications on Mesozoic megaspores compared to the Northern Hemisphere (see text-figures 1, 2 of Kovach \& Batten, 1989; Vajda \& McLoughlin, 2005). Of those published reports, few Gondwanan studies deal with Jurassic assemblages and only one (the illustration of a single species by Filatoff, 1975) documents a megaspore of this age from Australia. The Inverleigh assemblages are consistent with the cosmopolitan aspect of mid-Mesozoic floras developed at the peak of Pangean amalgamation (Meyen, 1987) in that they share several genera with Late TriassicEarly Cretaceous megaspore suites from diverse regions of the globe (see e.g. Banerji et al., 1984; Li et al., 1987; Koppelhus \& Batten, 1992; Baldoni \& Batten, 1997; Tosolini et al., 2002). However, in all but one case (Minerisporites alius), we recognise differences at the species level between the Inverleigh and extra-Australian assemblages. The assemblages identified in the Marburg Subgroup likely reveal only a small component of the full megaspore diversity in the Australian Jurassic, and we encourage further work in this field to realise the full biostratigraphic and biogeographic potential of this fossil group. 

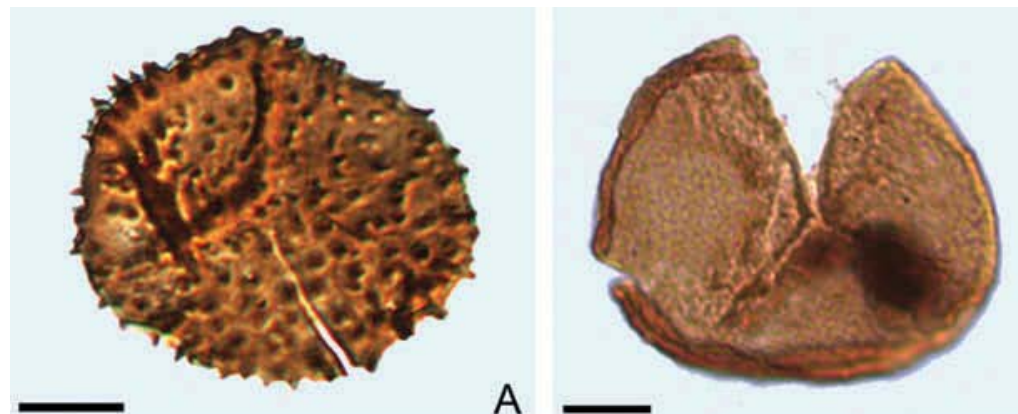

B
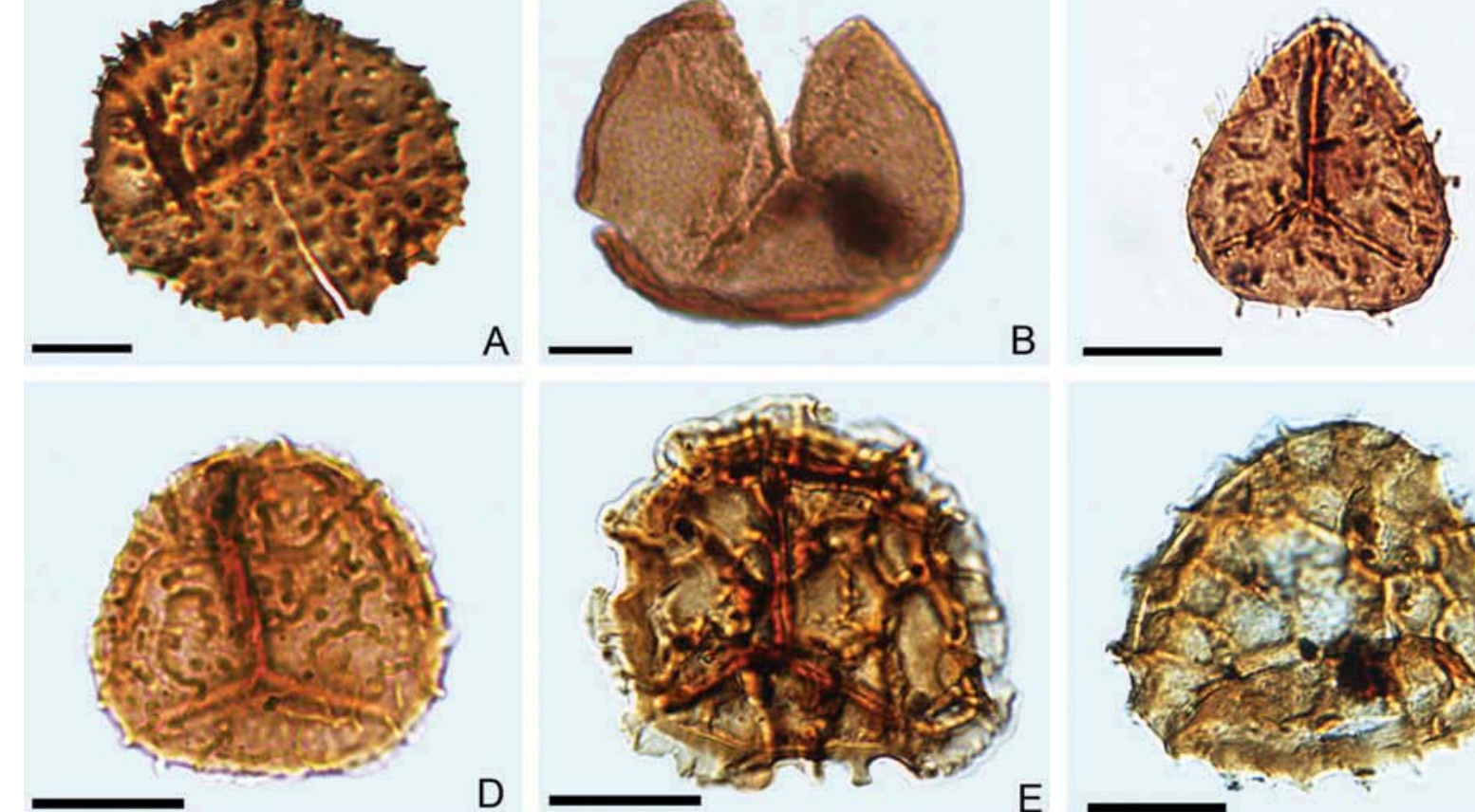

A
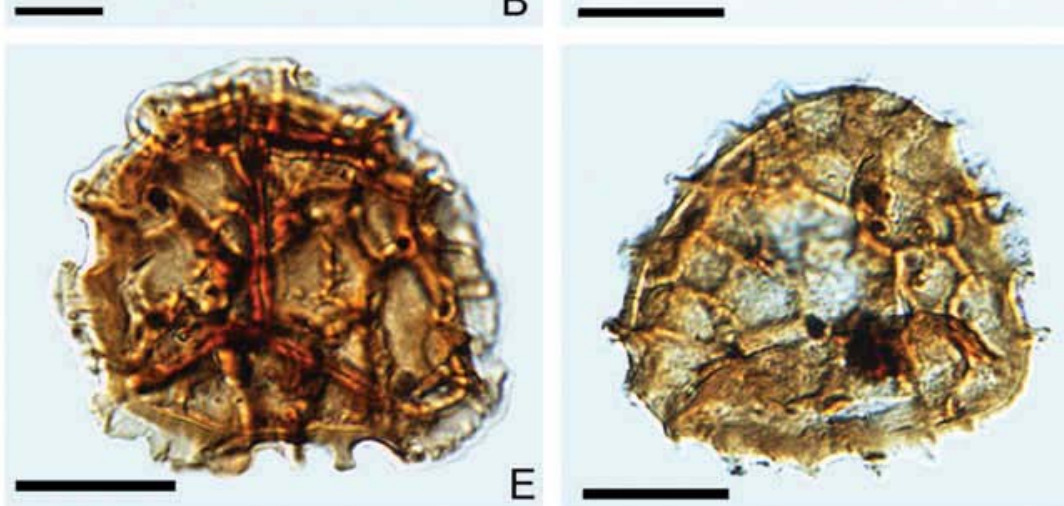

C
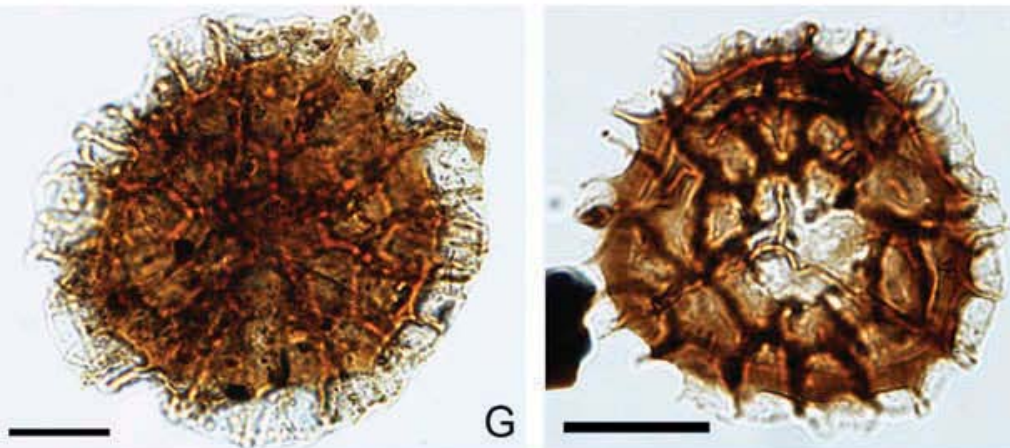

$\mathrm{E}$

F
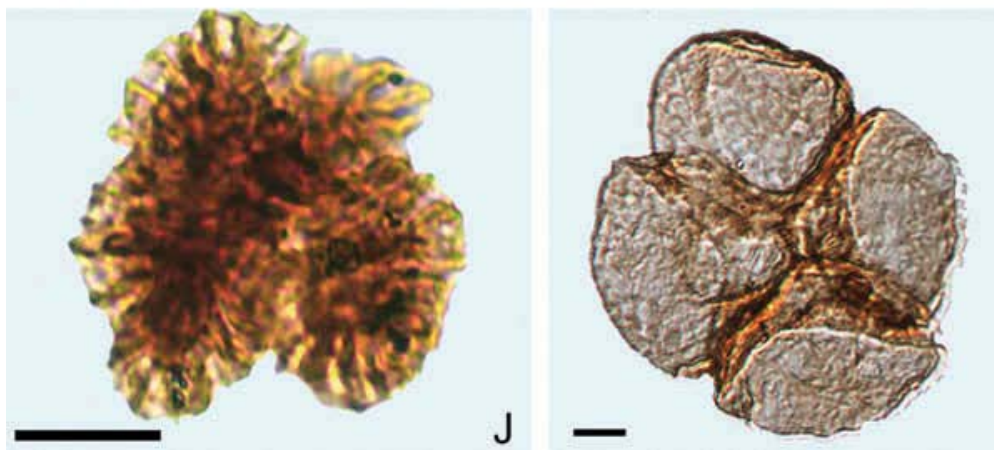

$\mathrm{H}$

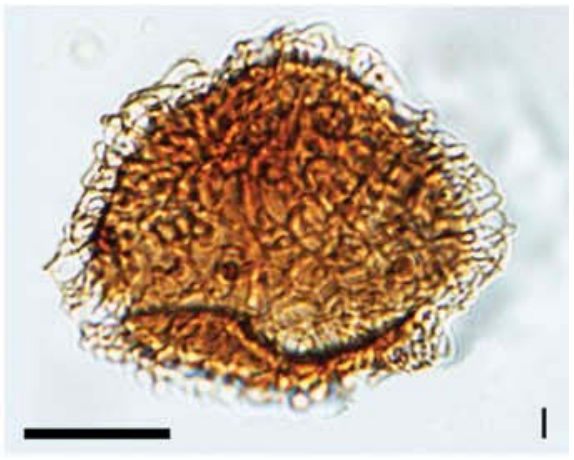

Figure 14. Light micrographs of representative lycophyte microspores and algal remains from the Marburg, Subgroup at Inverleigh. Taxon, sample number, England Finder Reference (EFR) and registration (LO) numbers. A. Ceratosporites helidonensis, INVB 4, EFR-P22/4, LO11868t. B. Densoisporites psilatus, INVB 2, EFR-K/17, LO11869t. C. Neoraistrickia sp., INVB 7, EFR-M25/2, LO11870t. D. Retitriletes semimuris, INVB 8, EFR-U20, LO11871t. E. Retitriletes clavatoides, INVB 10, EFR-Q18, LO11872t. F. Retitriletes rosewoodensis, INVA 2, EFR- U29/4, LO11873t. G, H. Retitriletes astroclavatidites: G. INVB 2, EFR-T25/4, LO11874t; H. INVB 9, EFR-U32, (LO11875t). I. Retitriletes sp., INVB 7 EFR-N18/4 LO11876t. J. Botryococcus braunii, INVB 1, W29/4, LO11877t. K. Quadrisporites sp., INVB 1, EFR-S39, LO11878t. L. Pediastrum sp., INVB 1, EFR-T36, LO11879t. Scale bars $-10 \mu \mathrm{m}$. 


\section{Comparison between the megaspore and microspore assemblages}

The relative abundance of lycophyte microspores (1.4-35.5\%; average $10 \%$ ) within the 13 productive samples is consistent with published data on Australian Jurassic palynomorph assemblages, which typically indicate relative abundances of 114\% (de Jersey, 1963, 1971, 1973; Reiser \& Williams, 1969). The lycophyte microspores are represented by eight genera whose affinities have traditionally been considered to lie with the Selaginellaceae and Lycopodiaceae based on morphological similarities to modern spores or to congeneric fossil spores preserved within fructifications (Dettmann, 1986; Balme, 1995; Raine et al., 2011; Table I). Relating the megaspore and microspore taxa in the Inverleigh assemblages is difficult, given that all occur in a dispersed state. However, comparison of the megaspore abundance data with that of the microspores (Table I) reveals some apparent discrepancies in the representation of lycophyte families. The most abundant megaspore taxon, Minerisporites alius, is of probable isoetacean affinity (Balme, 1995), whilst the most common microspores include Ceratosporites helidonensis (possible Lycopodiaceae/Selaginellaceae; Raine et al., 2011) and Retitriletes (Lycopodiaceae: Raine et al., 2011). We note that few microspores recorded from the Australasian Mesozoic have been considered affiliates of Isoetaceae (Dettmann, 1986; Balme, 1995; Raine et al., 2011), but based on the representation of megaspores and macrofossils, this ought not to be the case. Isoetaleans typically have small (commonly $<20 \mu \mathrm{m}$ long), ornamented monolete microspores (Macluf et al., 2010), and it is conceivable that some spores of this size could be lost in palynological processing using a $10 \mu \mathrm{m}$ sieve) or even separated by taphonomic winnowing in the depositional environment. However, their complete absence in the Australian Early Jurassic assemblages is surprising and not easily explained by these processes. Clearly, further studies of fossil isoetalean sporangia are warranted to clarify associations between microspores and megaspores, and to resolve their familial affinities.

\section{Palaeoenvironmental setting}

The abundance of ferns and isoetaleans in the Inverleigh deposit suggests a humid palaeoenvironment, as these groups both require moisture for gamete exchange, the latter tending to grow in consistently moist soils or even semi- to fully submerged settings (Taylor et al., 1993). This is consistent with the presence of extensive floodbasin facies incorporating dark palaeosols, invertebrate burrows and probable moisture-loving hirudinean (leech) traces in the studied succession. Small fragments of glossy black charcoal occur in all macerated samples indicating that fire was a consistent feature of the Early Jurassic landscape in the Clarence-Moreton Basin.

The macroflora preserved at the Inverleigh locality contains just one lycophyte, two fern and three gymnosperm foliage-based taxa. The mesofloras and palynofloras reveal a greater dimension to the fossil plant diversity. The single lycophyte macrofossil taxon is now supplemented by at least nine forms of megaspores (Table I) and 16 dispersed microspore taxa in eight genera (Appendix).

The presence of some abraded specimens suggests limited transport of a few megaspores, but the majority of both megaspores and microspores have wellpreserved ornamentation. Consequently, the microspore and megaspore suites probably constitute a fair

Table II. Palynomorph absolute diversity (number of species) in samples from the Marburg Subgroup at Inverleigh Quarry, differentiated according to inferred biological affinity.

\begin{tabular}{|c|c|c|c|c|c|c|}
\hline Sample & Bryophytes & Lycophytes & Ferns & Gymnosperms & Algae & All \\
\hline INVB10 & 3 & 4 & 5 & 6 & 0 & 18 \\
\hline INVA4 & 2 & 3 & 8 & 6 & 0 & 19 \\
\hline INVB9 & 2 & 4 & 6 & 4 & 1 & 17 \\
\hline INVB8 & 2 & 3 & 8 & 7 & 0 & 20 \\
\hline INVB7 & 3 & 6 & 8 & 8 & 0 & 25 \\
\hline INVA3 & 3 & 2 & 7 & 9 & 0 & 21 \\
\hline INVB5 & 1 & 5 & 9 & 6 & 0 & 21 \\
\hline INVB4 & 3 & 3 & 7 & 5 & 0 & 18 \\
\hline INVB3 & 3 & 3 & 6 & 13 & 0 & 25 \\
\hline INVA2 & 4 & 8 & 10 & 11 & 0 & 33 \\
\hline INVB2 & 1 & 4 & 3 & 7 & 1 & 16 \\
\hline INVB1 & 0 & 1 & 2 & 2 & 3 & 8 \\
\hline INVA1 & 1 & 6 & 8 & 6 & 2 & 23 \\
\hline Total diversity & 6 & 16 & 16 & 18 & 3 & 59 \\
\hline
\end{tabular}


representation of lycophyte diversity in the immediate floodbasin community. The delicate and easily detached and degraded leaves of isoetaleans, together with the general similarity of leaves belonging to various species within this clade, probably accounts for their low recognised macrofossil diversity and abundance.

There is no clear relationship between megaspore preservation and sedimentary facies, other than that the single sample from facies A yielded a diverse and abundant assemblage, and facies D was barren. Samples from facies B and C yielded assemblages of mixed quality, however strong dominance of algal spores in the basal part of the succession indicates a lacustrine depositional setting represented by the dark grey siltstones of lithofacies B. The presence of abundant isoetalean microphylls on some bedding planes (Jansson et al., 2008b, figure 5I) suggests that the parent plants grew very near the site of deposition (see also Sweet, 1979).

Likewise, the rich and well-preserved miospore flora represented throughout the studied succession reflects the evolution of the local floodbasin from a lake setting, to a periodically inundated and pteridophyte- and gymnosperm-vegetated floodplain, to eventually an active channel setting. Lycophyte microspores are present in similar relative abundances in all productive samples (with exception of the high abundance in sample INVB2). This shows that their occurrence is not strongly tied to a particular floodbasin facies. The bed producing the highest percentage of lycophyte microspores (INVB2) occurs directly above the eutrophic lake deposits that are overwhelmingly dominated by freshwater algae. This suggests that the lycophytes were pioneer colonisers of shallow-water substrates or moist lake-margin soils as the water body was infilled - an ecology matching that of modern isoetaleans (Garrett \& Kantvilas, 1992).

Lycophytes, particularly isoetaleans, may have played an especially important role in Early to mid-Mesozoic aquatic communities. The primary producers in pre-angiosperm continental freshwater communities were most likely micro- and macroalgae (especially charophytes; Martín-Closas, 2003), but isoetaleans may also have been important components of lake-margin, mire and streammargin communities providing a source of organic nutrients for aquatic herbivores and saprotrophs, and also acting as a growth substrate for algae and a range of colonial filter-feeding and grazing consumers. From the Barremian or Aptian, many of these niches appear to have been occupied by aquatic angiosperms, but prior to this, few seed plants appear to have adopted herbaceous aquatic/semiaquatic habits (Ponomarenko, 1996). Hence, isoetalean lycophytes likely occupied key producer niches in Triassic-Jurassic aquatic ecosystems and their little-studied megaspore and microspore suites highlight a much greater diversity and importance than has been recognised thus far from their macrofossil record.

Although the single sample from facies $\mathrm{D}$ was barren for palynomorphs, the coarse grain-size, large-scale bedforms, impressions of coarse woody debris, and intervening thin mud drapes hosting ripple marks and possible vertebrate ichnofossils indicates a shift to episodic high-energy in-channel deposition with intervening periods of waning flow and subaerial exposure in the upper part of the succession at Inverleigh. Preservation of ripple bedforms and vertebrate trackways is optimal on exposed but unconsolidated moist sediment surfaces (Thulborn, 1990, 2013; Vajda et al., 2013). The putative vertebrate tracks in the Inverleigh Quarry cannot be assigned to a trace-maker, but both dinosaurs and large temnospondyl amphibians are candidates, since both are known from body fossils or trackways in Lower Jurassic strata elsewhere in southern Queensland (Longman, 1941; Beeston \& Gray, 1993; Grant-Mackie et al., 2000).

\section{Conclusions}

Nine lycophyte megaspore taxa (including one new species: Paxillitriletes rainei) and assorted other mesofossils were recovered from an $8 \mathrm{~m}$ sampled interval of fluvial floodbasin strata within the Marburg Subgroup (Pliensbachian) at Inverleigh Quarry in the Clarence-Moreton Basin, southeast Queensland, Australia. Sixteen microspore taxa from a palynoflora of 59 taxa recovered from the same sampled interval are inferred to have lycophyte affinities. The megaspores may be either isoetalean or selaginellalean but the microspores have inferred affinities with the Selaginellales and Lycopodiales. Isoetalean corms and microphylls are the only lycophyte macrofossils known from the Inverleigh deposit. The difference between the megaspore, microspore and macrofossil diversities likely relates to the much greater yield of microspores in the samples, broader source areas, and potentially greater taxonomic segregation of morphotypes within this group. Lycophytes average c. $10 \%$ relative abundance (locally peaking at $35.5 \%$ ) in the 13 productive palyno-samples of the studied interval. Thus, lycophytes constitute a subordinate but consistent component of the Pliensbachian vegetation. This solid mesofossil and palynofloral representation 
contrasts with the meager record of only three lycophyte macrofossil taxa from the entire Australian Jurassic succession. The compositions of mesofossil and palynofossil assemblages do not show strong correlations to particular floodbasin lithofacies. Therefore, both mesofossils and palynofossils likely represent valuable tools for elucidating the diversity and abundance of lycophytes and other plant groups that have notoriously poor Mesozoic macrofossil records (e.g. bryophytes). Both eastern and western Australian basins host extensive coal-bearing Jurassic successions that are well-constrained biostratigraphically and offer great opportunities to further decipher the patterns of mid-Mesozoic vegetation change in southern middle to high palaeolatitudes via integrated macrofossil, mesofossil and palynofloral research.

\section{Acknowledgements}

Fieldwork in Australia was supported by the Moberg Scholarship to IMJ. Andrew Schnitzerling of Warwick Brick Works, Warwick, Queensland, Australia, is thanked for permitting access to the quarry site. SM was supported by grants from the Australian Research Council and Swedish Research Council (VR). VV acknowledges support from the Royal Swedish Academy of Sciences through the Knut and Alice Wallenbergs Foundation, the Swedish Research Council under grant LUCCI (Lund University Carbon Cycle Centre). The authors thank Rick Lupia and David Batten for their constructive reviews that helped improve the manuscript.

\section{References}

Akikuni, K., Hori, R. S., Vajda, V., Grant-Mackie, J. A. \& Ikehara, M. (2010). Stratigraphy of Triassic-Jurassic boundary sequences from the Kawhia coast and Awakino gorge, Murihiku Terrane, New Zealand. Stratigraphy, 7, 7-24.

Anderson, J. M., Anderson, H. M., Archangelsky, S., Bamford, M., Chandra, S., Dettmann, M. \& Rösler, O. (1999). Patterns of Gondwana plant colonisation and diversification. African Fournal of Earth Sciences, 28, 145-167.

Archangelsky, S. \& Villar de Seoane, L. (1989). Ultraestructura de dos nuevas megasporas Cretácicas de Santa Cruz, Argentina. Boletin de la Asociación Latinoamericano de Paleobotánica y Palinología, 12, 13-24.

Archangelsky, S. \& Villar de Seoane, L. (1990). Morfologia y estructura de megasporas Cretacicas de Patagonia. Republica Argentina. Revista Española Micropaleontología, 22, 419-450.

Archangelsky, S. \& Villar de Seoane, L. (1991). Notas sobre la flora fosil de la Tico, Provincia de Santa Cruz. XI. Morfologia y estructura de tres megasporas. Ameghiniana, $28,353-364$.

Ash, S. R. \& Pigg, K. B. (1991). A new Jurassic Isoetites (Isoetales) from the Wallowa Terrane in Hells Canyon, Oregon and Idaho. American fournal of Botany, 78, 1636-1642.
Backhouse, J. (1988). Late Jurassic and Early Cretaceous palynology of the Perth Basin, Western Australia. Geological Survey of Western Australia Bulletin, 135, 1-233.

Baldoni, A. M. \& Batten, D. J. (1991). Megaspores from the Lower Cretaceous Kachaike formation, Santa Cruz province, Argentina. Neues fahrbuch für Geologie und Paläontologie, Abhandlungen, 182, 377-393.

Baldoni, A. M. \& Batten, D. J. (1997). Cretaceous megaspores from two boreholes in the Austral Basin, Santa Cruz Province, Argentina, and their stratigraphic and palaeoenvironmental significance. Neues Fahrbuch für Geologie und Paläontologie, Abhandlungen, 205, 97-110.

Baldoni, A. M. \& Taylor, T. N. (1985). Megasporas Cretácicas de la Formacion Springhill en el subsuelo de Argentina y Chile Austral. Ameghiniana, 21, 151-167.

Balme, B. E. (1995). Fossil in situ spores and pollen grains: An annotated catalogue. Review of Palaeobotany and Palynology, 87, 81-323.

Banerji, J., Jana, B. N. \& Maheshwari, H. K. (1984). The fossil floras of Kachchh. II - Mesozoic megaspores. The Palaeobotanist, 33, 190-227.

Batten, D. J. (1969). Some British Wealden megaspores and their facies distribution. Palaeontology, 12, 333-350.

Batten, D. J. (1988). Revision of S.J. Dijkstra's Late Cretaceous megaspores and other plant microfossils from Limburg, The Netherlands. Mededelingen Rijks Geologische Dienst $41-3,1-55$

Batten, D. J. (1995). Megaspores from lowermost Aptian beds in northern Germany. Geologisches Fahrbuch, A, 141, 403-443.

Batten, D. J. (1998). Palaeoenvironmental implications of plant, insect and other organic-walled microfossils in the Weald Clay Formation (Lower Cretaceous) of southeast England. Cretaceous Research, 19, 279-315.

Batten, D. J., Colin, J.-P. \& Néraudeau, D. (2010). Megaspores from mid Cretaceous deposits in western France and their biostratigraphic and palaeoenvironmental significance. Review of Palaeobotany and Palynology, 161, 151-167.

Batten, D. J. \& Collinson, M. E. (2001). Revision of species of Minerisporites, Azolla and associated plant microfossils from deposits of the Upper Palaeocene and Palaeocene/Eocene transition in The Netherlands, Belgium and USA. Review of Palaeobotany and Palynology, 115, 1-32.

Batten, D. J. \& Koppelhus, E. B. (1993). Morphological reassessment of some zonate and coronate megaspore genera of mainly post-Palaeozoic age. Review of Palaeobotany and Palynology, 78, $19-40$.

Batten, D. J. \& Kovach, W. L. (1990). Catalogue of Mesozoic and Tertiary megaspores. American Association of Stratigraphic Palynologists Contribution Series, 24, 1-226.

Beattie, R. G. \& Avery, S. (2012). Palaeoecology and palaeoenvironment of the Jurassic Talbragar Fossil Fish Bed, Gulgong, New South Wales, Australia. Alcheringa, 36, 451-465.

Beeston, J. \& Gray, A. (1993). The ancient rocks of Carnarvon Gorge. Brisbane: Department of Minerals and Energy.

Bomfleur, B., Kerp, H., Taylor, T. N., Moestrup, Ø. \& Taylor, E. L. (2012). Triassic leech cocoon from Antarctica contains fossil bell animal. Proceedings of the National Academy of Sciences USA, 109, 20971-20974.

Burger, D. (1973). Palynological observations in the Carpentaria Basin, Queensland. Bureau of Mineral Resources, Geology and Geophysics, Australia, Bulletin, 140, 27-44.

Burger, D. (1976). Palynological observations in the Surat Basin. Appendix 5. In A. R. Jensen, N. F. Exon, J. C. Anderson \& W. H. Koppe (Eds.), A guide to the geology of the Bowen and Surat Basins in Queensland (pp. 51-54). Sydney: 25th International Geological Congress, Excursion Guide 3C. 
Burger, D. (1980). Early Cretaceous (Neocomian) microplankton from the Carpentaria Basin, northern Queensland. Alcheringa, 4, 263-279.

Burger, D. (1982). A basal Cretaceous dinoflagellate suite from northeastern Australia. Palynology, 6, 161-192.

Burger, D. (1994). Palynological studies of the Bundamba Group and Walloon Coal Measures in the Clarence-Moreton Basin. In A. T. Wells \& P. E. O'Brien (Eds.), Geology and petroleum potential of the Clarence-Moreton Basin, New South Wales and Queensland (pp. 164-180). Canberra: Australian Geological Survey Organisation Bulletin, 241.

Cantrill, D. J. \& Drinnan, A. N. (1994). Late Triassic megaspores from the Amery Group, Prince Charles Mountains, East Antarctica. Alcheringa, 18, 71-78.

Cantrill, D. J. \& Webb, J. A. (1998). Permineralized pleuromeid lycopsid remains from the Early Triassic Arcadia Formation, Queensland, Australia. Review of Palaeobotany and Palynology, 102, 189-211.

Collinson, M. E. (1991). Diversification of modern heterosporous pteridophytes. In S. Blackmore \& S. H. Barnes (Eds.), Pollen and spores. Patterns of diversification (pp. 119-150). Systematics Association Special Volume, 44. Oxford: Clarendon Press.

Cranfield, L. C., McElroy, C. T. \& Swarbrick, C. F. (1975). Clarence-Moreton Basin, N.S.W. and Q. In D. M. Traves \& D. King (Eds.), Economic geology of Australia and Papua New Guinea: Coal (pp. 328-333). Parkville: Australian Institute of Mining and Metallurgy.

de Jersey, N. J. (1963). Jurassic spores and pollen grains from the Marburg Sandstone. Geological Survey of Queensland Publication, 313, 1-15.

de Jersey, N. J. (1971). Early Jurassic miospores from the Helidon Sandstone. Geological Survey of Queensland Publication, 351, $1-49$.

de Jersey, N. J. (1973). Palynology of core samples from the Helidon, Toowoomba and Kulpi areas. Queensland Government Mining fournal, 74, 128-144.

de Jersey, N. J. (1975). Miospore zones in the lower Mesozoic of southeastern Queensland. In K. S. W. Campbell (Ed.), Gondwana geology: Papers from the 3rd Gondwana Symposium, Canberra, 1973 (pp. 159-172). Canberra: ANU Press.

de Jersey, N. J. \& McKellar, J. L. (2013). The palynology of the Triassic-Jurassic transition in southeastern Queensland, Australia, and correlation with New Zealand. Palynology, 37, 77-114.

de Jersey, N. J. \& Paten, R. J. (1964). Jurassic spores and pollen grains from the Surat Basin. Geological Survey of Queensland Publication, 322, 1-18.

de Jersey, N. J. \& Raine, J. I. (1990). Triassic and earliest Jurassic miospores from the Murihiku Supergroup, New Zealand. New Zealand Geological Survey Paleontological Bulletin, 62, 1-164.

Dettmann, M. E. (1961). Lower Mesozoic megaspores from Tasmania and South Australia. Micropaleontology, 7, 71-86.

Dettmann, M. E. (1986). Early Cretaceous palynoflora of subsurface strata correlative with the Koonwarra Fossil Bed, Victoria. Memoirs of the Association of Palaeontologists, 3, 79-110.

Dijkstra, S. J. (1951). Wealden megaspores and their stratigraphical value. Mededelingen van de Geologische Stichting, Nieuwe Serie, 5, 7-21.

Döring, H., Krutzsch, W., Mai, D. H. \& Schulz, E. (1963). Retitriletes. In W. Krutzsch (Ed.), Atlas der mittel- und jungtertiären dispersen Sporen- und Pollen- sowie der Mikroplanktonformen des nördlichen Mitteleuropas. Lieferung II (pp. 8-18). Berlin: Deutscher Verlag der Wissenschaften.

Douglas, J. G. (1969). The Mesozoic floras of Victoria. Parts 1 and 2. Memoirs of the Geological Survey of Victoria, 28, 1-310.

Evans, P. R. (1966). Mesozoic stratigraphic palynology in Australia. Australian Oil and Gas fournal, 12, 58-63.
Fielding, C. R. (1984). Upper delta plain lacustrine and fluviolacustrine facies from the westphalian of the Durham coalfield, NE England. Sedimentology, 31, 547-567.

Fielding, C. R. (1993). The Middle Jurassic Walloon Coal Measures in the type area, the Rosewood-Walloon Coalfield, SE Queensland. Australian Coal Geology, 9, 4-16.

Filatoff, J. (1975). Jurassic palynology of the Perth Basin, Western Australia. Palaeontographica Abt B, 154, 1-113.

Gamerro, J. C. (1975). Megasporas del Cretacico de Patagonia II. Megasporas petrificadas de la formación la Amarga, Cretácico inferior, prov. Neuquen. Acta Congreso Argentino De Paleontología Y Bioestratigrafía, 2, 11-28.

Garrett, M. \& Kantvilas, G. (1992). Morphology, ecology and distribution of Isoetes L. in Tasmania. Papers and Proceedings of the Royal Society of Tasmania, 126, 115-122.

Glaessner, M. P. \& Rao, V. R. (1955). Lower Cretaceous plant remains from the vicinity of Mount Babbage, South Australia. Transactions of the Royal Society of South Australia, 78, 134-140.

Goscombe, P. W. \& Coxhead, B. A. (1995). Clarence-Moreton, Surat, Eromanga, Nambour, and Mulgildie Basins. In C. R Ward, H. J. Harrington, C. W. Mallett \& J. W. Beeston (Eds.), Geology of Australian coal basins (pp. 489-511). Sydney: Geological Society of Australia Coal Geology Group Special Publication, 1.

Gould, R. E. (1968). Morphology of Equisetum laterale Phillips, 1829 , and E. bryanii sp. nov. from the Mesozoic of southeastern Queensland. Australian fournal of Botany, 16, 153-176.

Gould, R. E. (1971). Appendix 3. Report on plant fossils from Durikai, southeastern Queensland. In N. F. Exon, R. F. Reiser, D. J. Casey \& R. L. Brunker (Eds.), The postPalaeozoic rocks of the Warwick 1:250 000 Sheet area, Queensland and New South Wales (pp. 63-64). Canberra: Bureau of Mineral Resources, Geology and Geophysics, Australia, Report, 140.

Gould, R. E. (1974). The fossil flora of the Walloon Coal Measures: A survey. Proceedings of the Royal Society of Queensland, 85, 33-41.

Gould, R. E. (1975). The succession of Australian pre-Tertiary megafossil floras. Botanical Review, 41, 453-483.

Gould, R. E. (1980). The coal-forming flora of the Walloon Coal Measures. Coal Geology, 1, 83-105.

Grant-Mackie, J. A., Aita, Y., Balme, B. E., Campbell, H. J., Crallinor, A. B., MacFarlane, D. A. B. \& Thulborn, R. A. (2000). Jurassic palaeobiogeography of Australasia. Association of Australasian Palaeontologists Memoir, 23, 311-353.

Hall, J. W. \& Nicholson, D. H. (1973). Paxillitriletes, a new name for fossil megaspores hitherto invalidly named Thomsonia. Taxon, 22, 319-320.

Harris, T. M. (1961). The Yorkshire Furassic Flora 1. ThallophytaPteridophyta. London: British Museum (Natural History).

Helby, R., Morgan, R. \& Partridge, A. D. (1987). A palynological zonation of the Australian Mesozoic. Memoirs of the Association of Australasian Palaeontologists, 4, 1-94.

Hemsley, A. R., Collinson, M. E., Kovach, W. L., Vincent, B. \& Williams, T. (1994). The role of self-assembly in biological systems: Evidence from iridescent colloidal sporopollenin in Selaginella megaspore walls. Philosophical Transactions of the Royal Society of London, B, 345, 163-173.

Hill, R. S., Truswell, E. M., McLoughlin, S. \& Dettmann, M. E. (1999). The evolution of the Australian flora: Fossil evidence. In A. E. Orchard (Ed.), Flora of Australia, 2nd Edition, 1 (Introduction) (pp. 251-320). Melbourne: CSIRO.

Holdgate, G. R., McLoughlin, S., Drinnan, A. N., Finkelman, R. B. \& Willett, J. C. (2005). Inorganic chemistry, petrography and palaeobotany of Permian coals in the Prince Charles Mountains, East Antarctica. International fournal of Coal Geology, 63, 156-177. 
Holmes, P. L. (1994). The sorting of spores and pollen by water: Experimental and field evidence. In A. Traverse (Ed.), Sedimentation of organic particles (pp. 9-32). Cambridge: Cambridge University Press.

Jana, B. N. \& Ghosh, A. K. (1997). A megaspore assemblage from the Athgarh Formation and its bearing on the age of the formation. The Palaeobotanist, 46, 149-155.

Jansson, I.-M., McLoughlin, S. \& Vajda, V. (2008a). Early Jurassic annelid cocoons from eastern Australia. Alcheringa, 32, 285-296.

Jansson, I.-M., McLoughlin, S., Vajda, V. \& Pole, M. (2008b). An Early Jurassic flora from the Clarence-Moreton Basin, Australia. Review of Palaeobotany and Palynology, 150, 5-21.

Jones, O. A. \& de Jersey, N. J. (1947). Fertile Equisetales and other plants from the Brighton Beds. Papers of the Department of Geology, University of Queensland, 3, 1-17.

Karrfalt, E. (1986). New observations on the structure and development of Nathorstianella. Review of Palaeobotany and Palynology, 47, 1-8.

Kempf, E. K. (1971). Electron microscopy of Mesozoic megaspores from Denmark. Grana, 11, 151-163.

Koppelhus, E. B. \& Batten, D. J. (1989). Late Cretaceous megaspores from southern Sweden: Morphology and paleoenvironmental significance. Palynology, 13, 91-120.

Koppelhus, E. B. \& Batten, D. J. (1992). Megaspore assemblages from the Jurassic and lowermost Cretaceous of Bornholm, Denmark. Danmarks Geologiske Undersøgelse, DGU Serie A, 32, 5-81.

Kovach, W. L. \& Batten, D. J. (1989). Worldwide stratigraphic occurrences of Mesozoic and Tertiary megaspores. Palynology, 13, 247-277.

Kozur, H. (1973). Neue Megasporen aus dem Karn des Ilek-Beckens. Geologisch-Paläontologische Mitteilungen Innsbruck, 3, 1-12.

Kützing, F. T. (1849). Species algarum. Leipzig: F.A. Brockhaus.

Li, W., Batten, D. J., Zhang, D. \& Zhang, L. (1987). Early Cretaceous megaspores from the Jalainor Group of northeast Inner Mongolia, P.R. China. Palaeontographica Abt B, 206, 117-135.

Longman, H. A. (1941). A Queensland fossil amphibian. Memoirs of the Queensland Museum, 12, 29-32.

Lugardon, B., Grauvogel-Stamm, L. \& Dobruskina, I. (2000). Comparative ultrastructure of the megaspores of the Triassic lycopsid Pleuromeia rossica Neuburg. Comptes Rendus de l'Academie des Sciences, Paris, Série IIA, Sciences de la Terre et des Plantes, 330, 501-508.

Lundblad, A. B. (1950). Studies in the Rhaeto-Liassic floras of Sweden. I. Pteridophyta, Pteridospermae and Cycadophyta from the mining district of NW Scania. Kungliga Svenska Vetenskapsakademiens Handlingar, Fjärde Serien, 1, 1-82.

Lupia, R. (2011). Late Santonian megaspore floras from the Gulf Coastal Plain (Georgia, USA). Fournal of Paleontology, $85,1-21$.

Macluf, C., Esteban, I. M. T. \& Solís, S. M. (2010). Isoetes pedersenii, a new species from southern South America. Anais da Academia Brasileira De Ciências, 82, 353-359.

Mädler, K. (1954). Azolla aus dem Quartär und Tertiär sowie ihre Bedeutung für die Taxonomie älterer Sporen. Geologisches Fahrbuch, 70, 143-158.

Manum, S. B., Bose, M. N. \& Sawyer, R. T. (1991). Clitellate cocoons in freshwater deposits since the Triassic. Zoologica Scripta, 20, 347-366.

Marcinkiewicz, T. (1971). The stratigraphy of the Rhaetian and Lias in Poland based on megaspore investigations. Prace Instytutu Geologicznego, 65, 1-58 (in Polish with English summary).

Marcinkiewicz, T. (1992). The megaspore assemblage of Capillisporites germanicus from the Middle Triassic of Poland. Geological Quarterly, 36, 33-74.
Martín-Closas, C. (2003). The fossil record and evolution of freshwater plants: A review. Geologica Acta, 1, 315-338.

McKellar, J. L. (1974). Jurassic miospores from the upper Evergreen Formation, Hutton Sandstone, and basal Injune Creek Group, north-eastern Surat Basin. Geological Survey of Queensland Publication, 361, 1-89.

McKellar, J. L. (1981). Palynostratigraphy of samples from the Narangba area, Nambour Basin. Queensland Government Mining fournal, 82, 268-273.

McLoughlin, S. (1996). Early Cretaceous macrofloras of Western Australia. Records of the Western Australian Museum, 18, 19-65.

McLoughlin, S. \& Drinnan, A. N. (1995). A Middle Jurassic flora from the Walloon Coal Measures, Mutdapilly, Queensland, Australia. Memoirs of the Queensland Museum, 38, 257-272.

McLoughlin, S. \& Hill, R. S. (1996). The succession of Western Australian Phanerozoic floras. In S. D. Hopper, J. A. Chappill, M. S. Harvey \& A. S. George (Eds.), Gondwanan Heritage: Past, present and future of the Western Australian biota (pp. 6180). Sydney: Surrey Beatty.

McLoughlin, S., Lindström, S. \& Drinnan, A. N. (1997). Gondwanan floristic and sedimentological trends during the Permian-Triassic transition: New evidence from the Amery Group, northern Prince Charles Mountains, East Antarctica. Antarctic Science, 9, 281-298.

McLoughlin, S. \& Pott, C. (2009). The Jurassic flora of Western Australia. GFF, 131, 113-136.

McLoughlin, S., Tosolini, A.-M. P., Nagalingum, N. S. \& Drinnan, A. N. (2002). Early Cretaceous (Neocomian) flora and fauna of the lower Strzelecki Group, Gippsland Basin, Victoria. Memoirs of the Association of Australasian Palaeontologists, 26, 1-144.

Mehlqvist, K., Vajda, V. \& Larsson, L. (2009). An assemblage of a Middle Jurassic flora from Bornholm, Denmark - A study of a historic collection at Lund University, Sweden. GFF, 131, 137-146.

Meyen, S. V. (1987). Fundamentals of palaeobotany. London: Chapman and Hall.

Miall, A. D. (1977). A review of the braided river depositional environment. Earth Science Reviews, 13, 1-62.

Montoya, E., Rull, V. \& Vegas-Vilarrúbia, T. (2012). Non-pollen palynomorph studies in the Neotropics: The case of Venezuela. Review of Palaeobotany and Palynology, 186, 102-130.

Murray, N. (1939). The microflora of the Upper and Lower Estuarine Series of the East Midlands. Geological Magazine, $76,478-489$.

Neuburg, M. F. (1960). Pleuromeia Corda from the Lower Triassic deposits of the Russian platform. Trudy Geologičeskogo Instituta, Akademija Nauk SSSR, Stratigrafii, 43, 65-94 (in Russian).

O'Brien, P. E. \& Wells, A. T. (1994). Sedimentology of the Bundamba group. In A. T. Wells \& P. E. O'Brien (Eds.), Geology and petroleum potential of the Clarence-Moreton Basin, New South Wales and Queensland (pp. 72-137). Canberra: Australian Geological Survey Organisation, Bulletin, 241.

Pant, D. D. \& Mishra, S. N. (1986). On Lower Gondwana megaspores from India. Palaeontographica Abt B, 198, 13-73.

Pattemore, G. A. (2000). A new Jurassic pteridosperm fructification from Queensland. Fournal of African Earth Sciences, 31, 187-193.

Pattemore, G. A. \& Rigby, J. F. (2005). Fructifications and foliage from the Mesozoic of southeast Queensland. Memoirs of the Queensland Museum, 50, 329-345.

Phillips, T. L. \& Leisman, G. A. (1966). Paurodendron, a rhizomorphic lycopod. American fournal of Botany, 53, 1086-1100.

Pigg, K. B. (1992). Evolution of isoetalean lycopsids. Annals of the Missouri Botanical Garden, 79, 589-612. 
Playford, G. \& Dettmann, M. E. (1965). Rhaeto-Liassic plant microfossils from the Leigh Creek Coal Measures, South Australia. Senckenbergiana Lethaea, 46, 127-181.

Ponomarenko, A. G. (1996). Evolution of continental aquatic ecosystems. Paleontological fournal, 30, 705-709.

Potonié, R. (1956). Synopsis der Gattungen der Sporae dispersae 1. Teil: Sporites. Beihefte Zum Geologischen fahrbuch, 23, 1-103.

Punt, W., Hoen, P. P., Blackmore, S., Nilsson, S. \& Le Thomas, A. (2007). Glossary of pollen and spore terminology. Review of Palaeobotany and Palynology, 143, 1-81.

Raine, J. I. (2008). Zonate lycophyte spores from New Zealand Cretaceous to Paleogene strata. Alcheringa, 32, 99-127.

Raine, J. I., Mildenhall, D. C. \& Kennedy, E. M. (2011). New Zealand fossil spores and pollen: An illustrated catalogue. GNS Science Miscellaneous Series No. 4. Accessed 12 August 2013. Retrieved from http://data.gns.cri.nz/sporepollen/index. htm

Reiser, R. F. \& Williams, A. J. (1969). Palynology of the Lower Jurassic sediments of the northern Surat Basin, Queensland. Geological Survey of Queensland Publication, 339, 1-24.

Retallack, G. J. (1977). Reconstructing Triassic vegetation of eastern Australia: A new approach for the biostratigraphy of Gondwanaland. Alcheringa, 1, 247-278.

Retallack, G. J. (1997). Earliest Triassic origin of Isoetes and quillwort evolutionary radiation. Fournal of Paleontology, 71, 500-521.

Rigby, J. F. (1978). Jurassic plant fossils from the Walloon Coal Measures at Rosewood Consolidated Colliery. Queensland Government Mining fournal, 78, 320-325.

Rust, B. R. \& Jones, B. G. (1986). The Hawkesbury Sandstone south of Sydney, Australia: Triassic analogue for the deposits of a large, braided river. Fournal of Sedimentary Petrology, 57, 222-233.

Ryberg, P. E., Taylor, E. L. \& Taylor, T. N. (2012). Permineralized lycopsid from the Permian of Antarctica. Review of Palaeobotany and Palynology, 169, 1-6.

Schwendemann, A. B., Decombeix, A.-L., Taylor, E. L. \& Taylor, T. N. (2010). Collinsonites schopfii gen. et sp. nov., a herbaceous lycopsid from the Upper Permian of Antarctica. Review of Palaeobotany and Palynology, 158, 291-297.

Scott, A. C. \& Playford, G. (1985). Early Triassic megaspores from the Rewan Group, Bowen Basin, Queensland. Alcheringa, 9, 297-323.

Seward, A. C. (1904). On a collection of Jurassic plants from Victoria. Records of the Geological Survey of Victoria, 1, 155-211.

Seward, A. C. \& Sahni, B. (1920). Indian Gondwana plants: A revision. Memoirs of the Geological Survey of India, Palaeontologia Indica (N.S.), 7, 1-55.

Singh, H. P., Srivastava, S. K. \& Roy, S. K. (1964). Studies on the Upper Gondwana of Cutch - 1. Mio- and macrospores. The Palaeobotanist, 12, 282-306.

Slater, B. J., McLoughlin, S. \& Hilton, J. (2011). Guadalupian (Middle Permian) megaspores from a permineralised peat in the Bainmedart Coal Measures, Prince Charles Mountains, Antarctica. Review of Palaeobotany and Palynology, 167, 140-155.

Slater, B. J., McLoughlin, S. \& Hilton, J. (2012). Animal-plant interactions in a Middle Permian permineralised peat of the Bainmedart Coal Measures, Prince Charles Mountains, Antarctica. Palaeogeography, Palaeoclimatology, Palaeoecology, 363-364, 109-126.

Steinthorsdottir, M. \& Vajda, V. (2013). Early Jurassic (late Pliensbachian) $\mathrm{CO}_{2}$ concentrations based on stomatal analysis of fossil conifer leaves from eastern Australia. Gondwana Research, http://dx.doi.org/10.1016/j.gr.2013.08.021.

Sukh Dev (1961). The fossil flora of the Jabalpur series-3. Spores and pollen grains. The Paleobotanist, 8, 43-56.
Sweet, A. R. (1979). Jurassic and Cretaceous megaspores. American Association of Stratigraphic Palynologists, Contribution Series, 5B, 1-30.

Taylor, W. C., Luebke, N. T., Britton, D. M., Hickey, R. J. \& Brunton, D. F. (1993). Isoëtaceae Reichenbach. In G. W. Argus, et al. (Eds.), Flora of North America (Vol. 2, pp. 6475). Oxford: Oxford University Press.

Thulborn, R. A. (1990). Dinosaur tracks. London: Chapman and Hall.

Thulborn, R. A. (2013). Lark Quarry revisited: A critique of methods used to identify a large dinosaurian track-maker in the Winton Formation (Albian-Cenomanian), western Queensland, Australia. Alcheringa, 37, 312-330.

Tosolini, A.-M., McLoughlin, S. \& Drinnan, A. N. (2002). Early Cretaceous megaspore assemblages from southeastern Australia. Cretaceous Research, 23, 807-844.

Tosolini, A.-M. P. \& Pole, M. (2010). Insect and clitellate annelid traces in mesofossil assemblages from the Cretaceous of Australasia. Alcheringa, 34, 397-419.

Townrow, J. A. (1968). A fossil Selaginella from the Permian of New South Wales. Fournal of the Linnean Society, Botany, 61, 13-23.

Turner, S., Bean, L. B., Dettmann, M., McKellar, J., McLoughlin, S. \& Thulborn, T. (2009). Australian Jurassic sedimentary and fossil successions: Current work and future prospects for marine and non-marine correlation. GFF, 131, 49-70.

Vajda, V. (2001). Aalenian to Cenomanian palynofloras of SW Scania, Sweden. Acta Paleontologica Polonica, 46, 403-426.

Vajda, V., Calner, M. \& Ahlberg, A. (2013). Palynostratigraphy of dinosaur footprint-bearing deposits from the Triassic-Jurassic boundary interval of Sweden. GFF, 135, 120-130.

Vajda, V. \& McLoughlin, S. (2005). A new MaastrichtianPaleocene Azolla species from Bolivia, with a comparison of the global record of coeval Azolla microfossils. Alcheringa, 29, 305-329.

Vajda, V. \& McLoughlin, S. (2007). Extinction and recovery patterns of the vegetation across the Cretaceous-Palaeogene boundary - a tool for unravelling the causes of the end-Permian mass-extinction. Review of Palaeobotany and Palynology, 144, 99-112.

Veevers, J. J. (2000). Billion-year earth history of Australia and neighbours in Gondwanaland. Sydney: GEMOC Press.

Walkom, A. B. (1928). Fossil plants from Plutoville, Cape York Peninsula. Proceedings of the Linnean Society of New South Wales, 53, 145-150.

Walkom, A. B. (1944). Fossil plants from Gingin, W.A. fournal of the Royal Society of Western Australia, 28, 201-207.

Webster, T. R. (1992). Developmental problems in Selaginella (Selaginellaceae) in an evolutionary context. Annals of the Missouri Botanical Garden, 79, 632-647.

Wells, A. T. \& O'Brien, P. E. (1994). Lithostratigraphic framework of the Clarence-Moreton Basin. In A. T. Wells \& P. E. O'Brien (Eds.), Geology and petroleum potential of the ClarenceMoreton Basin, New South Wales and Queensland (pp. 4-47). Canberra: Australian Geological Survey Organisation, Bulletin, 241.

White, M. E. (1981a). Revision of the Talbragar Fish Bed flora (Jurassic) of New South Wales. Records of the Australian Museum, 33, 695-721.

White, M. E. (1981b). Cylomeia undulata (Burges) gen. et comb. nov., a lycopod of the Early Triassic strata of New South Wales. Records of the Australian Museum, 33, 723-734.

White, M. E. (1986). The greening of Gondwana. Frenchs Forest: Reed Books.

Wierer, J. F. (1998). Vergleichende Untersuchungen an Mega-sporenvergesellschaftungen der alpinen und germanischen Mittelund Obertrias. Münchner Geowissenschaftliche Abhandlungen Reihe A: Geologie und Paläontologie, 35, 1-176. 


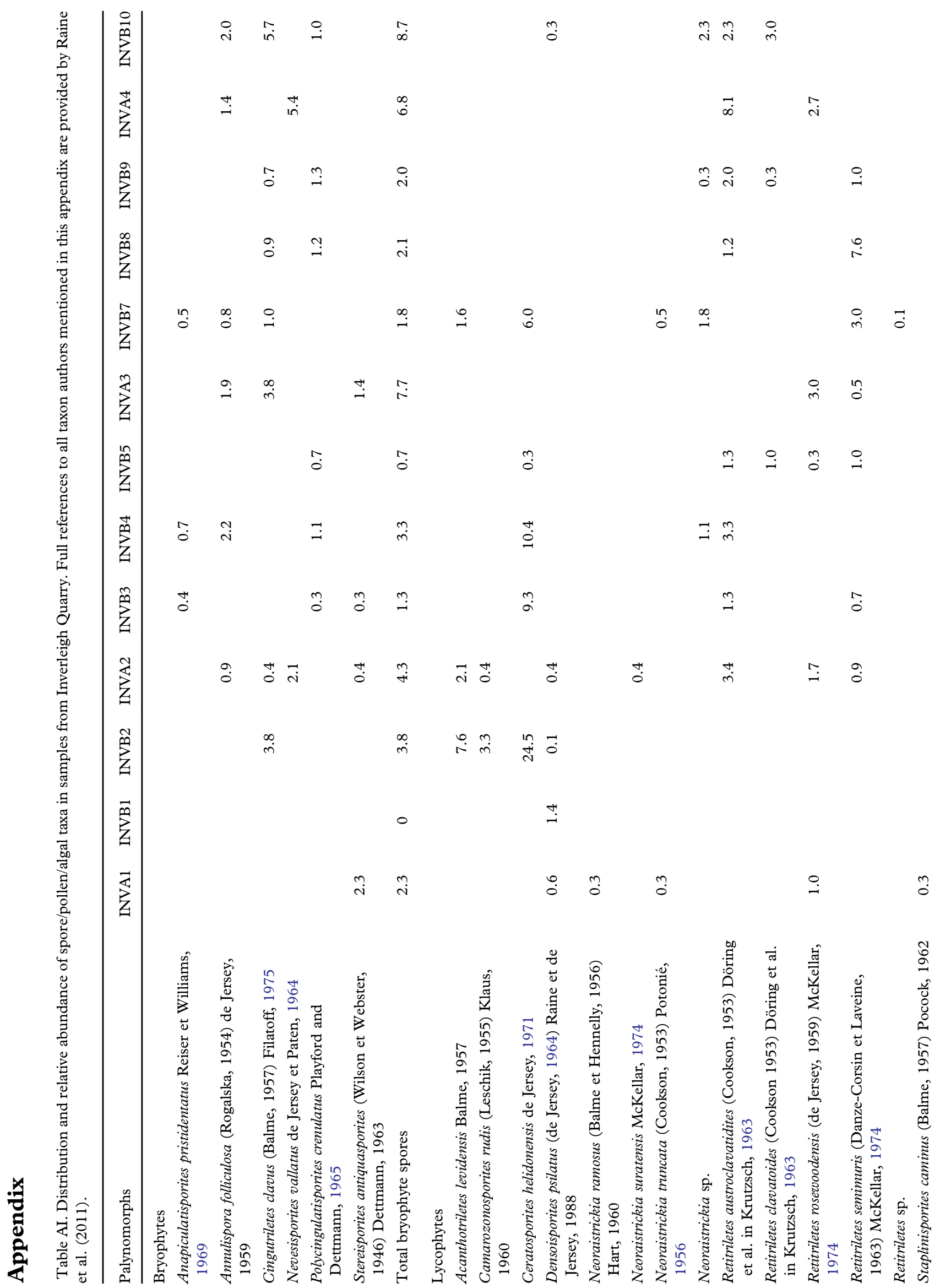




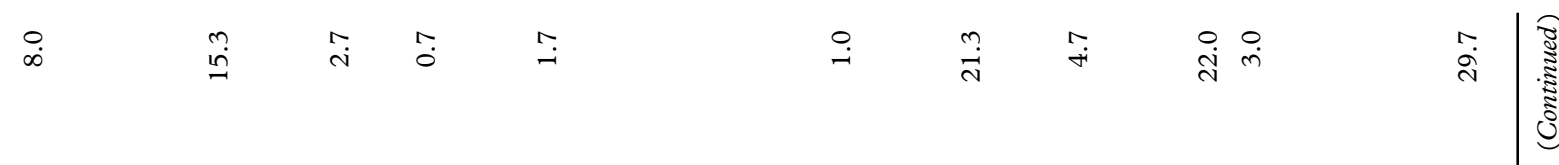

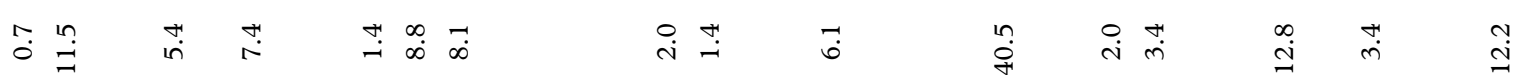

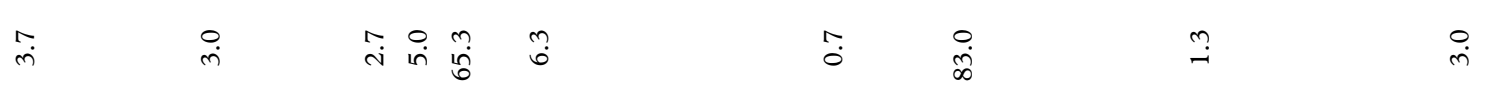

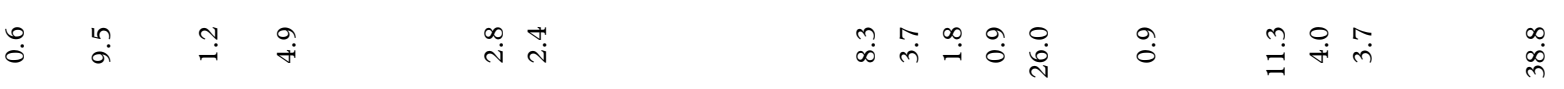

$$
\begin{aligned}
& \vec{m} \quad \text { in }
\end{aligned}
$$

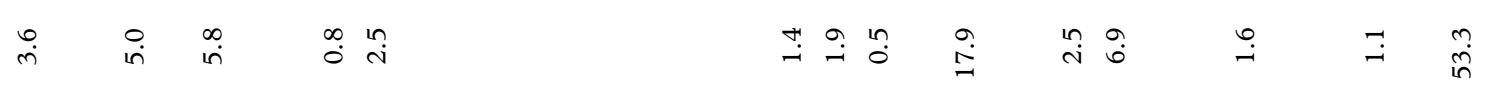

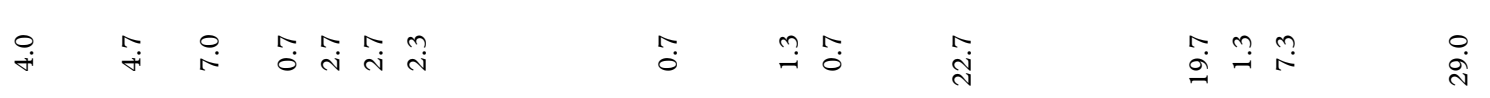

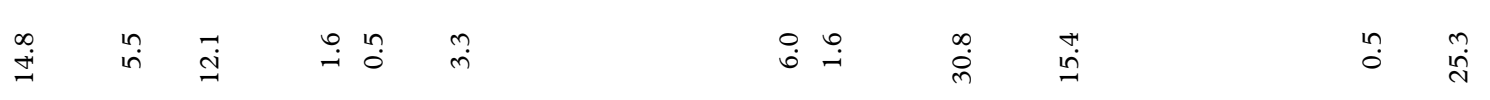

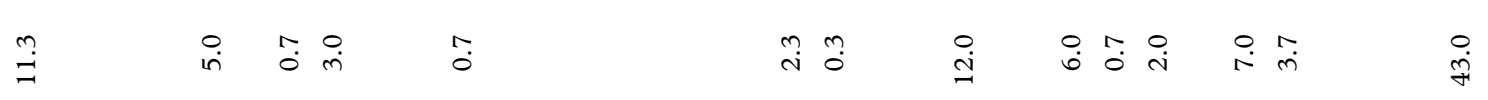

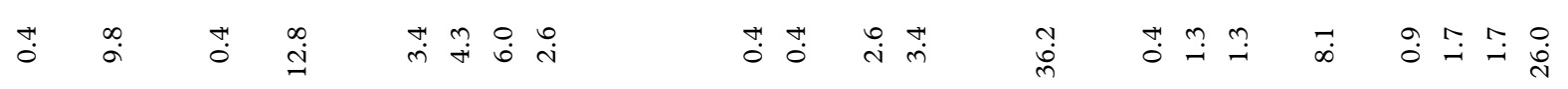

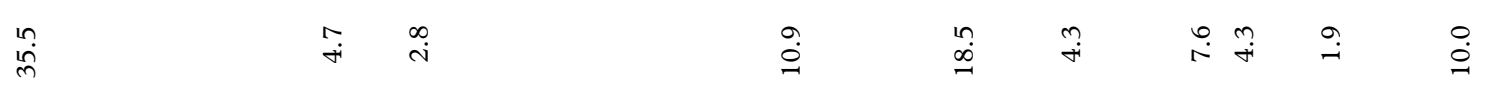

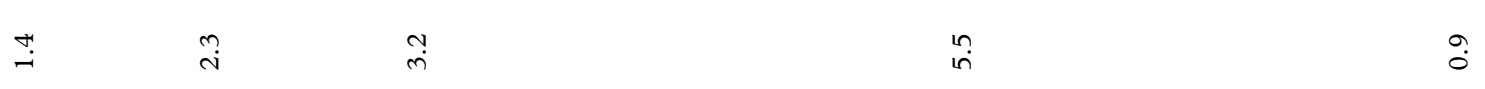

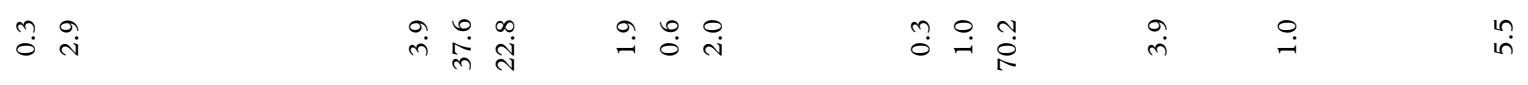

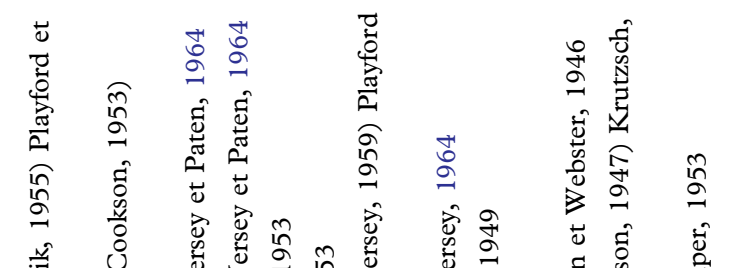

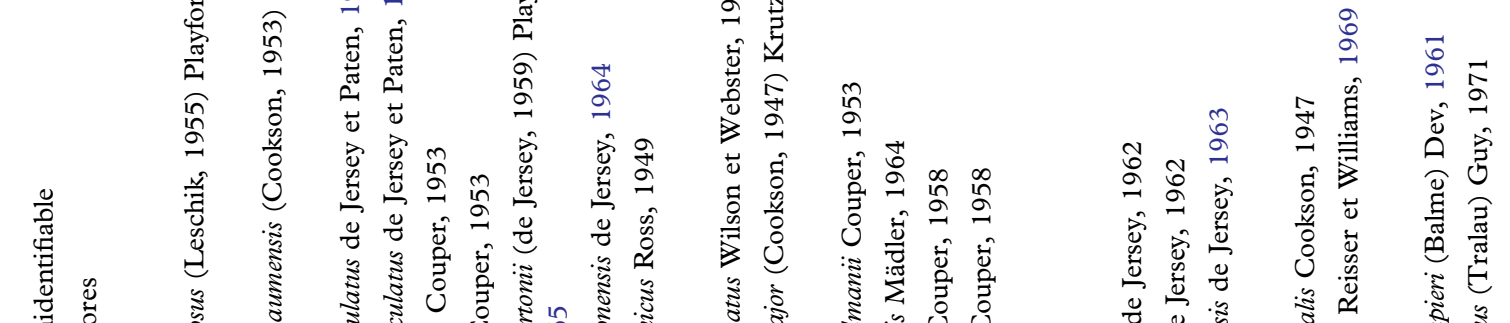

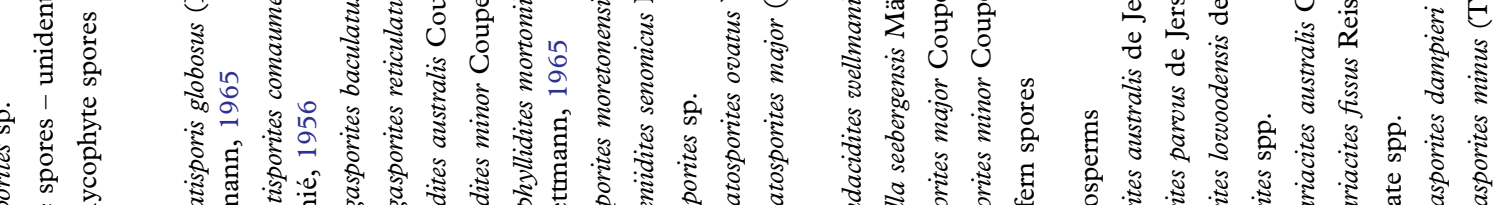

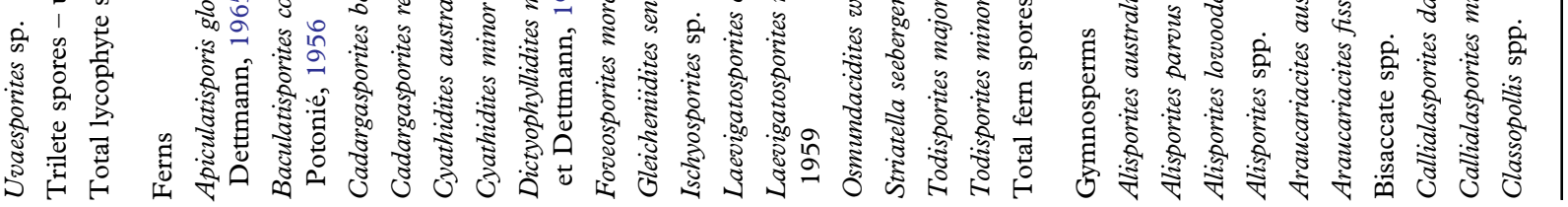


S. McLoughlin et al.

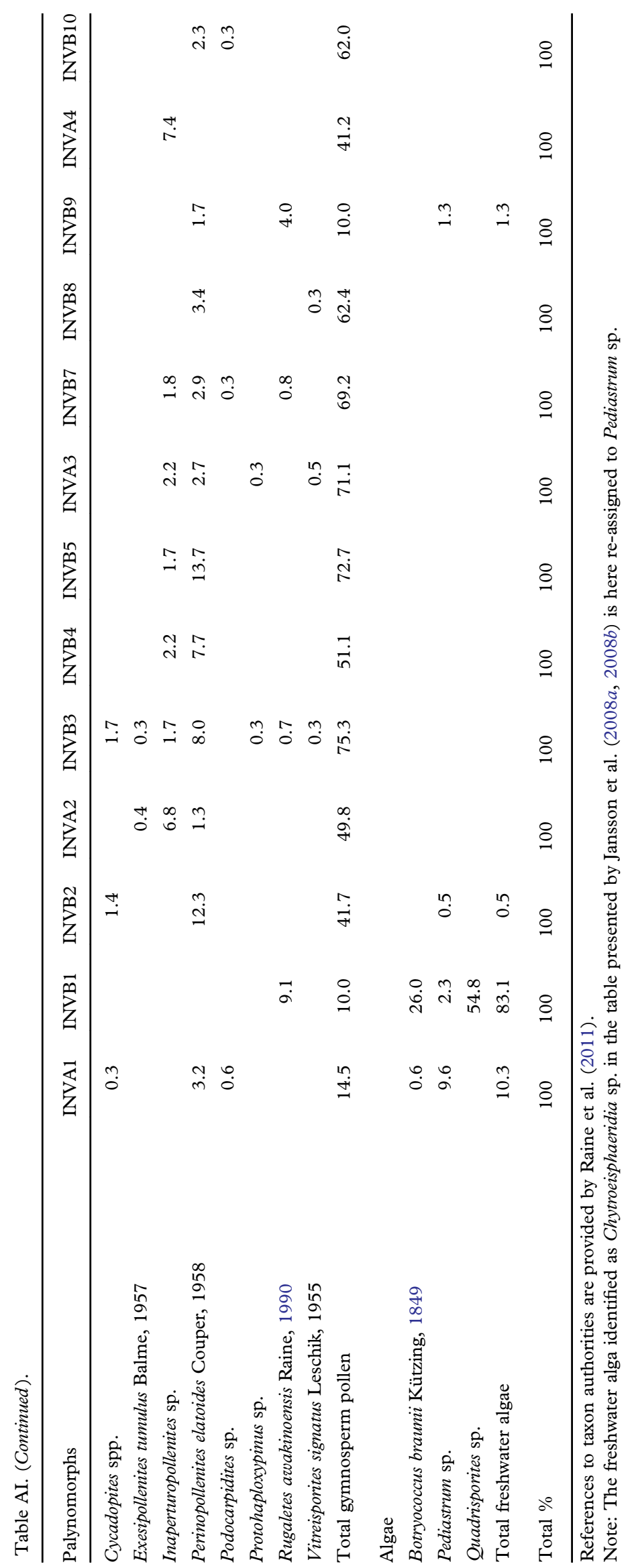

